\title{
WPS4028
}

\section{Fiscal and Social Impact of a Nominal Exchange Rate Devaluation in Djibouti}

\author{
by Paloma Anós Casero and Ganesh Seshan ${ }^{1}$
}

\begin{abstract}
Limited fiscal space limits Djibouti's ability to meet the Millennium Development Goals and improve the living conditions of its population. Djibouti's fiscal structure is unique in that almost 70 percent of government revenue is denominated in foreign currency (import taxes, foreign aid grants and military revenue) while over 50 percent of government expenditure is denominated in local currency (wages, salaries and social transfers). Djibouti's economic structure is also unusual in that merchandise exports of local origin are insignificant, and the country relies heavily on imported goods (food, medicines, consumer and capital goods). A currency devaluation, by reducing real wages, could potentially generate additional fiscal space that would help meet Djibouti's fundamental development goals. Using macro and household level data, this paper quantifies the impact of a devaluation of the nominal exchange rate on fiscal savings, real public sector wages, real income and poverty, under various hypothetical scenarios of exchange-rate pass-through and magnitude of devaluation. We find that a currency devaluation could indeed generate fiscal savings in the short-term, but it would have an adverse effect on poverty and income distribution. A 30 percent nominal exchange rate devaluation could generate fiscal savings amounting between 3 and 7 percent of GDP. At the same time, a 30 percent nominal devaluation could cause nearly a fifth of the poorest households to fall below the extreme poverty line and pull the same fraction of upper middle-income households below the national poverty line. We also find that currency devaluation could generate net fiscal savings even after accounting for the additional social transfers needed to compensate the poor for their real income loss. However, the absence of formal social safety nets limits the government's readiness to provide well-targeted and timely social transfers to the poor.
\end{abstract}

This paper aims at providing some empirical evidence of the potential fiscal and social impact of currency devaluation in Djibouti drawing on household survey data. In this regard, the paper does not aim to provide economic policy recommendations on exchange rate management nor does it represent the views of the World Bank or the government of Djibouti.

\section{World Bank Policy Research Working Paper 4028, October 2006}

The Policy Research Working Paper Series disseminates the findings of work in progress to encourage the exchange of ideas about development issues. An objective of the series is to get the findings out quickly, even if the presentations are less than fully polished. The papers carry the names of the authors and should be cited accordingly. The findings, interpretations, and conclusions expressed in this paper are entirely those of the authors. They do not necessarily represent the view of the World Bank, its Executive Directors, or the countries they represent. Policy Research Working Papers are available online at http://econ.worldbank.org.

\footnotetext{
${ }^{1}$ Paloma Anós Casero is a Senior Economist at the Middle East and North Africa Region, Social and Economic Development Group (MNSED). Ganesh Kumar Seshan is a consultant (ETC) at the Middle East and North Africa, Social and Economic Development Unit, World Bank, Washington D.C. For queries, email: panoscasero@worldbank.org
} 


\section{Table of Contents}

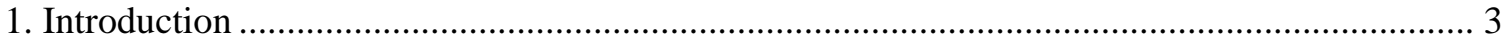

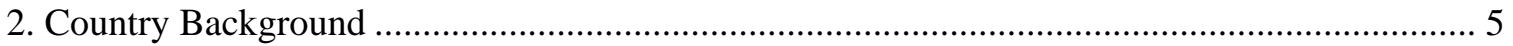

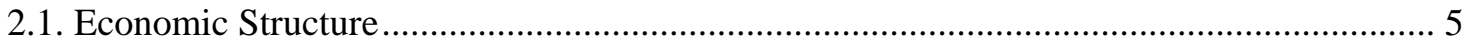

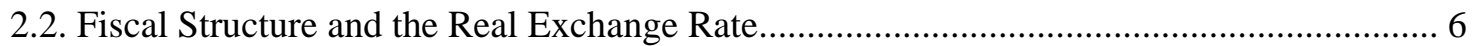

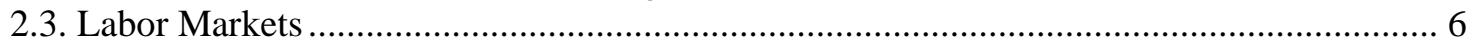

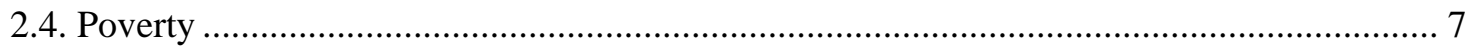

3. Estimating the Pass-Through Effect of a Nominal Exchange Rate Devaluation ....................... 10

4. Estimating the Fiscal Impact of a Nominal Exchange Rate Devaluation.................................. 11

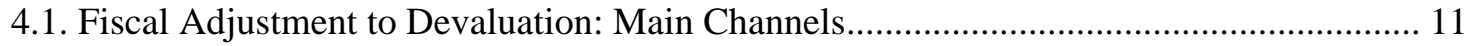

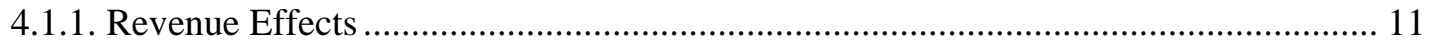

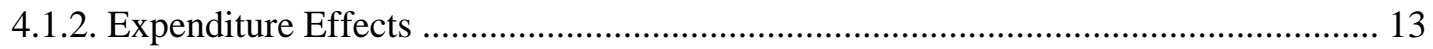

4.1.3. Estimating the Real Fiscal Savings from a Nominal Exchange Rate Devaluation..... 14

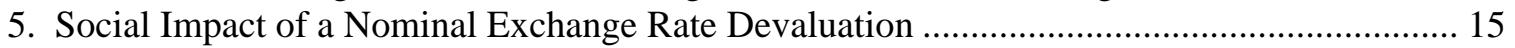

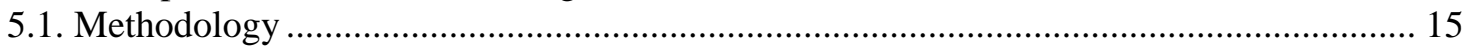

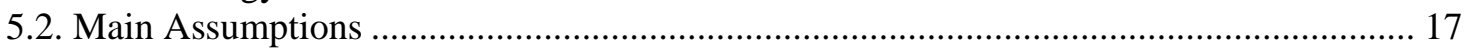

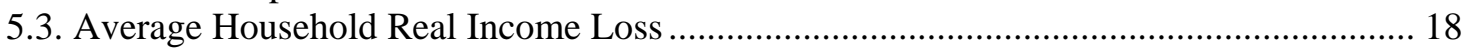

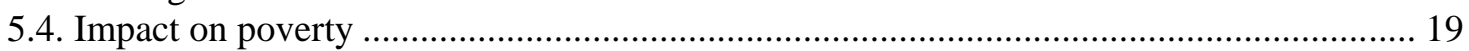

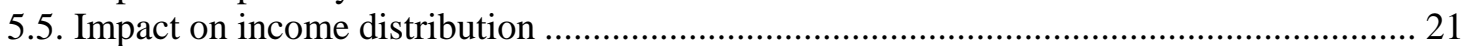

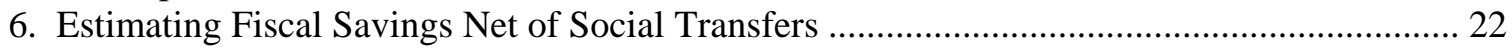

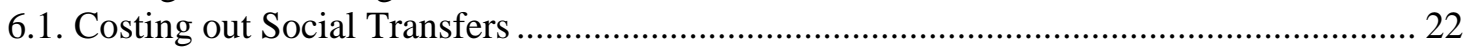

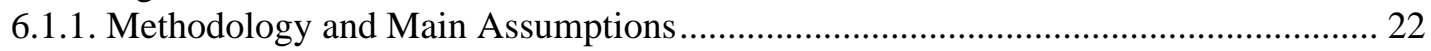

6.1.2. Costing out the social transfers needed to compensate the poor for their real income

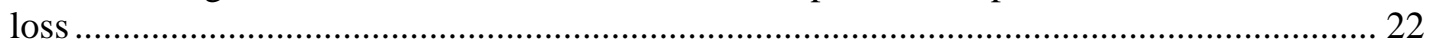

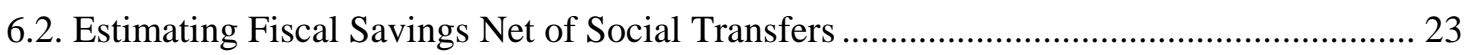

6.2.1. Methodology and Main Assumptions ...................................................................... 23

6.2.2. Fiscal savings of a nominal exchange rate devaluation net of social transfers ............ 24

6.3. Estimating net fiscal savings of a nominal exchange rate devaluation assuming wage

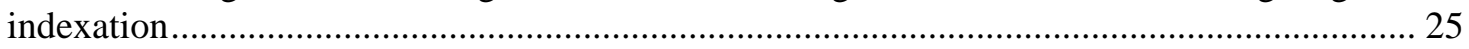

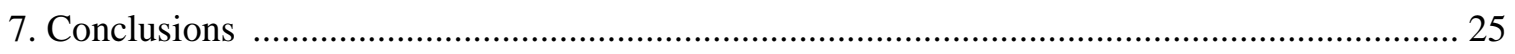

Annex 1. Main Transmission Channels Through Which A Currency Devaluation Could Affect

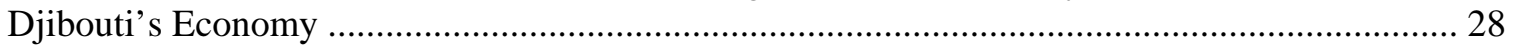

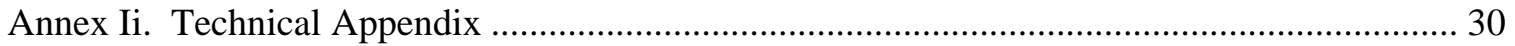




\section{Introduction}

The government of Djibouti is committed to meet the Millennium Development Goals (MDGs) and to rapidly improve the living conditions of its population. But high factor costs and limited fiscal space stand in the way of meeting these fundamental development goals. Despite considerable progress over recent years, Djibouti's public sector wage bill is one of the largest among developing countries. It represented nearly 14 percent of GDP in 2004, 60 percent of total fiscal revenues, almost 50 percent of total current expenditures, and more than 40 percent of total government expenditures leaving little fiscal space for social spending. ${ }^{2}$ The annual average pay of a civil servant is about 10 times the country's GNI per capita. High public sector wages serve as a benchmark for private sector wages putting upward pressure on unit labor costs. The high public sector wages also contribute to the cost of publicly owned energy, water and telephone utilities. These high production costs are a barrier to growth and indirectly to poverty reduction, by crowding out other government spending on productive investment and basic social services.

The Djibouti authorities have made policy choices to address the high factor cost problem and reduce the fiscal burden of the wage bill - but their effectiveness has proved limited. The Djibouti's policy intentions have been to implement fiscal and structural reforms to reduce the high production costs while maintaining a fixed exchange rate regime. The government is committed to implement structural reforms, including: revising the investment, labor and commerce codes and privatizing management of publicly-owned utilities (electricity, water and telecommunications). On the fiscal front, the Djibouti authorities are also committed to contain the public sector wage bill through retiring eligible civil servants, demobilizing military personnel hired during the civil war in the mid 1990's and instituting a freeze on new hiring in non-priority sectors. However, the implementation of these reforms has proceeded at a slow pace and the public sector wage bill and utility tariffs remain high.

A currency devaluation is an alternative policy option to reduce factor costs and create fiscal space to reallocate expenditure towards the attainment of MDGs and poverty reduction. Currency devaluation is typically considered in response to balance-of-payments difficulties and as a policy option to improve export competitiveness and growth prospects. In Djibouti, given the structural features of its economy, a nominal exchange rate devaluation is likely to be contractionary in the short-run (see footnote and Annex 1) ${ }^{3}$. The interest of considering a currency devaluation lies on its impact on the fiscal accounts. Djibouti's fiscal structure is such that its main sources of revenue (namely foreign grants and military aid) are denominated in

\footnotetext{
${ }^{2}$ The high level and the structure of civil pay was inherited from the French colonial administration and has changed little since independence. By virtue of Djibouti's currency board system (under which the nominal exchange rate has not changed since 1971), inflation is only about 2 percent, which does little to adjust real wages down as in other developing countries.

${ }^{3}$ Unlike many developing countries, Djibouti has a limited productive capacity of tradable goods and services, a marginal agricultural sector and a large non-tradable urban sector. As a result, the aggregate supply response of the tradable sector to reduced real wages will be limited, at least in the short-term. At the same time, a currency devaluation is likely to have a negative impact on aggregate demand. Private consumption is likely to fall due to the real income loss that households will experience as a result of the devaluation. Most of the consumption basket consists of tradable goods and most of the labor income is generated in the non-tradable service sector. A currency devaluation may also have a negative impact in the private investment demand in the non-tradable sector given the high dependency of the economy on imported intermediate and capital goods. The overall investment demand is likely to fall as the limited expected supply response of the tradable sector would remain insufficient to offset the negative impact on the private investment demand in the non-tradable sector. In addition, in Djibouti half of the deposits are in foreign currency. If the public attempts to convert domestic currency denominated deposits and liquidate its foreign exchange debts, this could lead to higher interest rates, which would tend to increase contractionary pressures on investment.
} 
foreign currency while most of the expenditures (with the wage bill absorbing half of the budget) are largely denominated in domestic currency. Thus, a nominal exchange rate devaluation could generate short-term fiscal savings that could be reallocated for poverty reduction purposes.

However, a currency devaluation could have a considerable negative impact on poverty. In Djibouti, unlike many developing countries, tradable goods make up a significant share of poor household's consumption baskets (over 60 percent). Tradable goods and services include food staples, qhat, medicines, clothing, housing, water, electricity gas and other fuels, furnishing, domestic equipment, health, transportation, hotels, cafes and restaurants. Food staples and qhat alone account for over 80 percent of the share of tradables in total household expenditure. In rural areas, poor households' consumption baskets are even more biased towards tradable goods, reflecting the larger share of food staples in consumption. Furthermore, the degree of import substitution is limited owing to the country's weak domestic productive capacity and the poor natural conditions for the development of agriculture. On the other hand, poor household's labor income is mostly derived from non tradable services. The proportion of labor earnings from the tradable sector is low and rises slightly as household consumption increases. The lack of formal safety nets and the strong reliance of poor households on informal transfers from family members employed in the public sector calls for a careful assessment of the potential social costs associated with a nominal exchange rate devaluation.

\section{This paper seeks to answer three main questions :}

What would be the short-term fiscal gain of a nominal exchange rate devaluation?

(ii) What would be the social cost associated with a devaluation of the Djibouti franc?

(iii) What would be the net fiscal gain of a nominal exchange rate devaluation (after accounting for the social transfers needed to compensate the poor for their real income loss)?

Holding other things constant, the answers to these questions will be dependent on the magnitude of the devaluation, the degree of exchange-rate pass-through to domestic prices and the degree of public sector wage indexation. To answer these questions the paper proceeds in sequential steps. First, it estimates the exchange rate pass-through to domestic prices. Second, it moves on to quantify the potential short-term fiscal impact of a nominal exchange rate devaluation drawing on a static, partial equilibrium model. Third, it proceeds to quantify the potential short-term social impact (in terms of average real income loss per household; impact on incidence and depth of poverty and on overall income distribution) using available household survey data ${ }^{4}$. Fourth, it estimates the total amount of social transfers that would be needed to compensate the poor (including poor households that become poorer after the devaluation; and those who are not poor but fall below the poverty line after the devaluation).

\section{The paper's main findings are as follows:}

\footnotetext{
${ }^{4}$ The two most recent household surveys in Djibouti were conducted in 1996 and 2002. This paper draws on the 1996 household survey (EDAM-I) because its design was better suited for the analysis. While the composition of household expenditure and sectoral labor participation patterns are similar in both surveys, the 2002 survey point to a deterioration in overall poverty and unemployment levels. Therefore, the preliminary estimates reported in the paper may underestimate the social impact of a currency devaluation in Djibouti.
} 
- A currency devaluation could generate fiscal savings in the short-term. A 30 percent nominal exchange rate devaluation could generate short-term fiscal savings amounting between 3 and 7 percent of GDP ( depending on the degree of exchange rate pass-through).

- However, a devaluation of the Djibouti franc will have a significant negative short-term impact on poverty. Assuming a nominal exchange rate devaluation of 30 percent and exchange pass-through of 60 percent, the number of households below the national poverty line could rise by 5 to 6 percentage points. Over 17 percent of households in the lowest consumption quartile could fall below the subsistence or extreme poverty line. About 20 percent of middle-income households (in the third quartile of the income distribution) could fall below the national poverty line.

- A currency devaluation could still generate fiscal savings even after accounting for the social transfers that would be needed to compensate the poor for their real income loss. A nominal exchange rate devaluation of 30 percent could still generate fiscal savings between 1 and 3 percent of GDP (depending on the degree of exchange rate pass-through) even after accounting for the social transfers that would be needed to compensate the poor for their real income loss.

- Yet, the lack of formal safety nets limits the government's readiness to provide welltargeted and timely social transfers to compensate the poor for their real income loss caused by a currency devaluation. Irrespective of the policy option chosen to address the high factor cost problem and the high public sector wage bill, setting up an effective system of social safety nets should be a short-term priority. Adequate safety nets will help the government address the needs of the poor in good economic times and be adaptable to combat the adverse effect of eventual shocks.

The remainder of the paper is organized as follows. Section 2 provides the country background, sketching the main features of Djibouti's economy and describes recent exchange rate and fiscal developments. Section 3 estimates the exchange pass-through drawing on available household survey data. Section 4 develops an empirical model of the real exchange rate and the fiscal sector to quantify the real fiscal savings of nominal exchange rate devaluation. Section 5 estimates the impact on poverty and income distribution of the devaluation drawing on available household survey data. Section 6 estimates the amount of social transfers that would be needed to compensate the poor for their real income loss and computes the fiscal savings generated by a currency devaluation after accounting for social transfers. Section 7 concludes with some policy implications.

\section{Country Background}

\subsection{Economic Structure}

Djibouti has a limited domestic productive capacity and the tertiary sector dominates the economy. Djibouti is poorly endowed with natural resources (limited arable land, rainfall, and underground water). Domestic production remains limited, owing to the harsh climate, high production costs, and the paucity of skilled workers. The country's small internal market and high factor costs limit its manufacturing potential. Agriculture and manufacturing accounted together for only 6 percent of GDP in 2004. The tertiary sector dominates the economy, contributing about 80 percent to gross domestic product (GDP) in 2004. With the exception of port-related services, military logistics services and tourism, most services are classified as non-tradables. These 
services include public administration, electricity, water, financial services to the expatriate community, commerce, communications and transport services.

Merchandise exports of local origin are insignificant, and the country relies almost entirely on imported food and consumer goods. Merchandise exports produced in Djibouti are limited, consisting mainly of live animals and skins. About 80 percent of good exports are actually reexports that go through Djibouti's port. Djibouti's main sources of foreign exchange earnings are official grants, military aid, receipts from services to the expatriate community, and port revenues from re-exporting goods to foreign military personnel and neighboring countries. Good imports represented over 55 percent of GDP in 2004.

\subsection{Fiscal Structure and the Real Exchange Rate}

Djibouti fiscal structure suggests potential fiscal savings from a currency devaluation. Revenues are largely denominated in foreign currency while expenditures are largely denominated in domestic currency. Djibouti's government revenue relies heavily on import taxes (around 30.3 percent of total revenue in 2004), foreign aid grants (19.2 percent of revenue) and military revenue (17.8 percent of revenues), all of which are denominated in foreign currency. On the other hand, the wage bill and transfers make up over 50 percent of total expenditure, and these expenditures are denominated in domestic currency terms.

Real fiscal revenues move in tandem with the real exchange rate. During the last two decades the Djibouti real effective exchange rate has experienced a strong appreciation that has been reversed in the last few years. Figure 1 shows the movement of the real (CPI based) effective exchange rate index, real fiscal revenue index and real government expenditure index between 1980 and 2004. All values are shown with 1996 as the base year and deflated with the GDP deflator except for the REER. For comparative purposes, the REER is redefined such that a falling level should be taken as an appreciation while a rising trend indicates depreciation. The REER has appreciated by 61 percent between 1980 and 2001, though a turning point appears to have taken place in 2002 where the REER started to depreciate.

\subsection{Labor Market}

Source: Authors' calculations based on WEO 2004.

The non-tradable sector is labor intensive. Household survey data indicates that 80 percent of the employed labor force is concentrated in public administration, tourism and commerce and other general services that serve domestic demand.

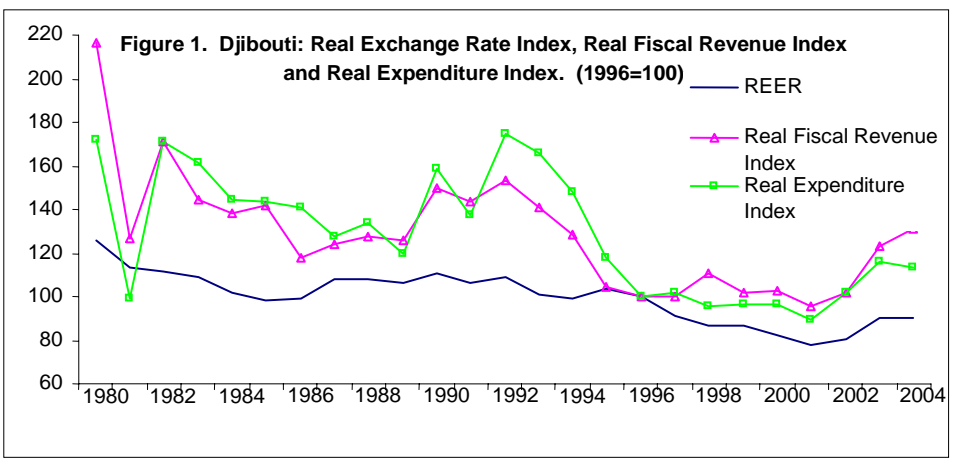

High nominal wages in the public sector drive up labor costs in the economy. The average public sector wage in Djibouti is 9 to 10 times the country's income per capita and 5 to 10 times the average public sector wage in Ethiopia and Yemen. Because the public sector wages are used as a benchmark for private sector wages, they drive up labor costs, deterring firm expansion and job creation.

The official unemployment rate is high, at about 56 percent in 2002. Youth employment is also a serious matter, where almost 90 percent of Djiboutians between 15 and 20 years old are 
unemployed. High unemployment rate in conjunction with low labor force participation rate imply that only a small fraction of Djibouti nationals are engaged in formal wage employment. Less than 20 percent in 1996 and 40 percent in 2002 of the population aged 15 and above were employed in the formal sector 5 .

\subsection{Poverty}

Poverty is high and rising. Despite its relatively high per capita income (with a GNI per capita of US\$1,030 in purchasing power parity terms), Djibouti has some of the highest rates of poverty in Sub-Saharan Africa (over 42 percent of its population lives below US\$2 a day). Increased poverty is the legacy from almost two decades of slow growth, lackluster private investment, and a fastgrowing unskilled labor force. Over the past two decades, real GDP growth averaged about 1 percent per year. With an average annual population growth rate of 2.5 percent, this weak economic performance led to a continued decline in real income per capita. The stark decline in per capita income explains the deterioration in poverty levels. Figures 2 and 3 provide a description of where the majority of households are located in terms of their per-capita expenditure for 1996 and 2002 respectively. Over the 6 year period, the rapid deterioration in economic well-being can be seen in the left-ward shift of the mass of the population, falling below the extreme poverty line by 2002 .

Poverty is more widespread in the rural and urban areas outside the city of Djibouti and surrounding districts. The incidence of rural poverty is over seven times greater to the incidence of urban poverty. Furthermore, the condition of the rural poor has further deteriorated over time. In 2002, 83 percent of rural Djiboutians were living in extreme poverty, unable to meet even basic nutritional needs as compared to 45.1 percent in 1996.

Figure 2: Poverty Incidence \& Share of Tradables in Total Household Expenditure, 1996

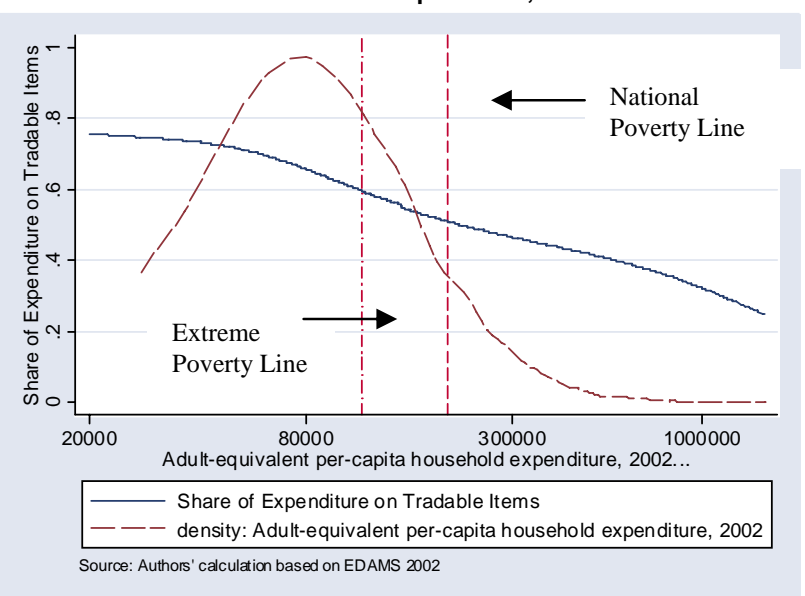

Figure 3: Incidence of Poverty \& Share of Tradables in Total Household Expenditure, 2002

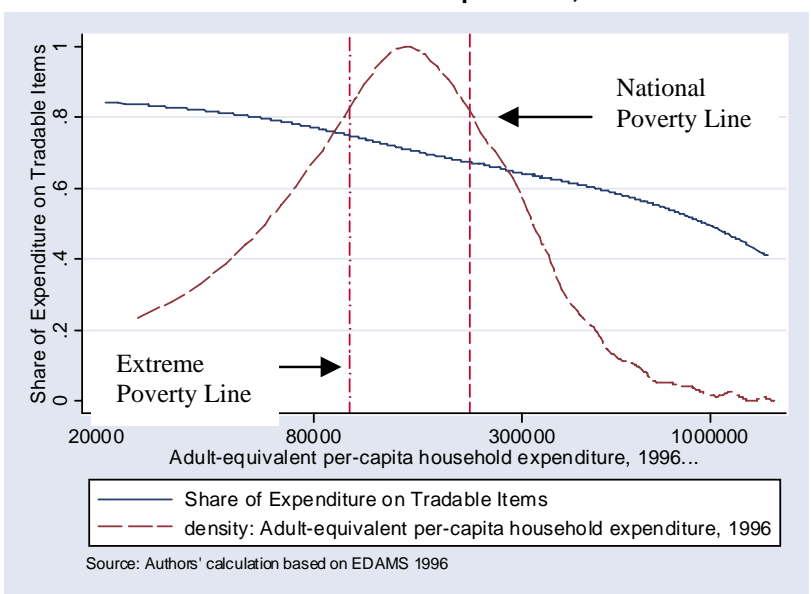

The consumption of the poor is heavily concentrated on food. As household income rises, the share of food in the total budget declines. The poorest households in the first income quartile ${ }^{6}$ spend 57.1 percent of their total expenditure on food in contrast to 30.4 percent incurred by the richest households as seen in the first column of Table 1. Interestingly, the qhat share in total

\footnotetext{
${ }^{5}$ Unemployment figures should be read with caution, because they may also include underemployment. Partly owing to weak formal insurance mechanisms, very few individuals can afford to be jobless in Djibouti. As a result, many workers undertake any type of work in the informal sector. See Chapter 3 of the 2005 Djibouti Country Economic Memorandum for further details on the labor market.

${ }^{6}$ Income quartiles are derived using per-capita adult equivalent household annual expenditure which is a common proxy for income.
} 
expenditure rises from 3.5 percent in the lower quartile to 14.7 percent to the richest quartile which alludes to better-off households purchasing more expensive qhat (probably of higher quality).

In Djibouti, unlike many other developing countries, the poor consume a disproportionately large share of tradable goods. Table 1 shows that tradable goods ${ }^{7}$ (of which food makes up the largest share) accounts for more than 76 percent of the overall expenditure of households in the first income quartile. This declines to 57 percent for the richest group in the forth quartile. The share of tradable is even large for rural households again due to the contribution of food consumption. Figure 2 and 3 illustrates the negative relationship between the share of tradable in overall household expenditure and adult-equivalent consumption for both 1996 and 2002, respectively.

Table 1 Djibouti: Household Expenditure Share of Tradable Goods, 1996

\begin{tabular}{|l|ccc|ccc|}
\hline \multirow{2}{*}{ Income Categories } & \multicolumn{3}{|c|}{ All Djibouti } & \multicolumn{3}{c|}{ Rural Area } \\
\cline { 2 - 7 } & food & qhat & tradables & food & qhat & tradables \\
\hline \multirow{2}{*}{ All } & 42.7 & 9.5 & 66.2 & 58.0 & 8.3 & 79.5 \\
poorest & 57.1 & 3.5 & 76.2 & 65.7 & 3.7 & 71.5 \\
2nd quartile & 45.2 & 7.5 & 67.6 & 49.5 & 10.5 & 61.5 \\
3rd quartile & 38.1 & 12.2 & 63.8 & 46.0 & 20.1 & 52.1 \\
richest & 30.4 & 14.7 & 57.3 & 33.9 & 24.1 & 42.9 \\
\hline
\end{tabular}

Note: Budget shares are expressed as a percentage of total household expenditure.

Source: Authors' calculation based on EDAM 1996.

While most Djiboutians earn labor income from the non-tradable sector, better-off households earn a higher share of their labor income from the public sector in contrast to poorer households. Figure 4 shows the modest contribution of labor earnings from the tradable sector ${ }^{8}$ which rises slightly with per-capita adult equivalent household consumption. Better-off households earn a higher share of their wage incomes from the public sector in contrast to poorer households as indicated in Figure $5^{9}$.

\footnotetext{
${ }^{7}$ Tradable goods based on the 1996 survey data consist of tobacco, qhat, school supplies, clothing and medical drugs while non-tradable goods and services are water and electric expenses, rent, health services and transportation

${ }^{8}$ Tradable sectors include manufacturing, retail and port services. The retail trade involves local distribution (a nontradable component), but given the small size of the country this component is not significant.

${ }^{9}$ In the first quartile, the poorest household share of public sector wages in overall labor income is 18.3 percent, rising to 38 percent for the richest group (the fourth quartile).
} 
Figure 4 : Share of Labor Income from Tradable Sector, 1996

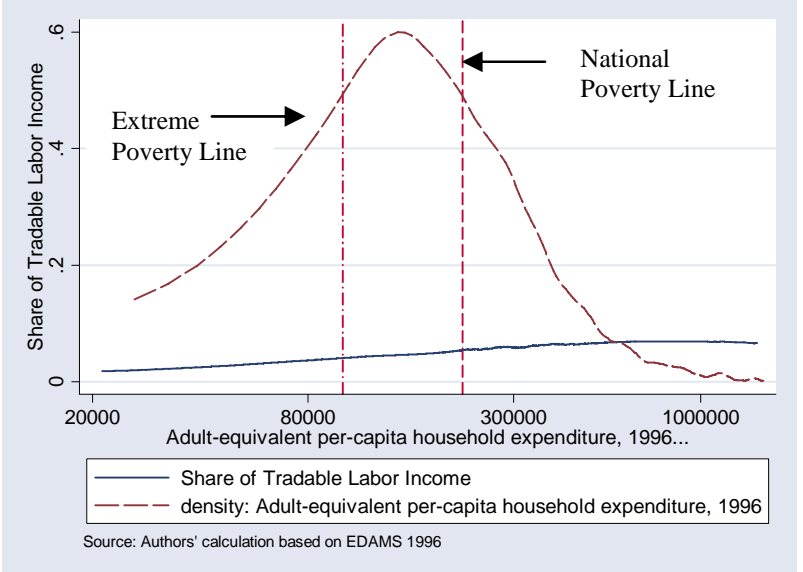

Figure 5 : Share of Labor Income from the Public Sector, 1996

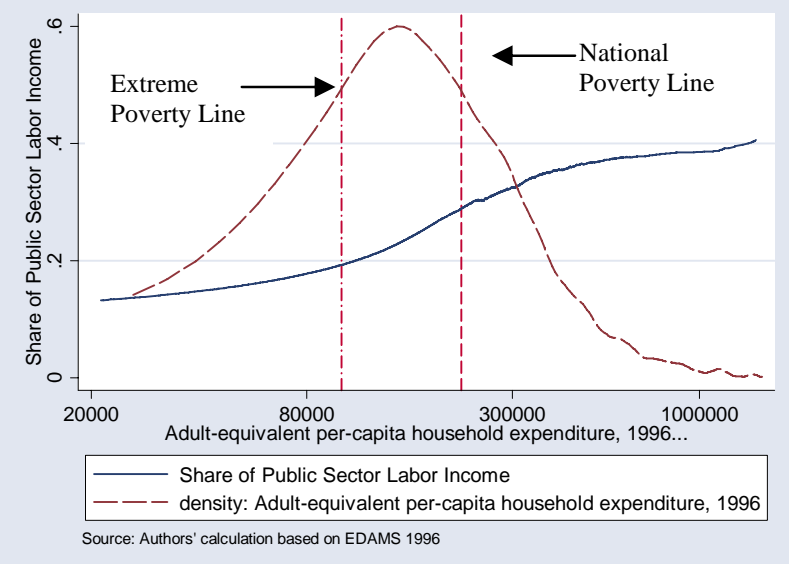

Djibouti does not have formal safety nets to protect the poor from real income losses. The poor are supported informally by remittances from relatives living abroad or from better-off relatives living in Djibouti. Table 2 shows net remittances as a share of total household expenditure. While the poorest households are net recipients, receiving equivalent of 7 percent of their total consumption, the richest households tend to be net distributors of remittances as indicated by the negative sign. High wages and other fringe benefits currently form the bulk of current expenditures, limiting the fiscal space to redistribute income to the poor. Non-wage allowances (pensions, health and family allowances, and other stipends) benefit primarily the upper-middle class. Access to the social security benefits depends on formal sector employment (mostly public sector employment), which is reserved largely for the middle class. The bottom decile, which includes the indigent population, receives only 4 percent of total government cash transfers - that is, 60 percent less than an average person. This contrasts with the eighth decile, which receives twice the average, and the tenth decile, which receives about the average amount of transfers. In Djibouti, virtually no formal safety nets (government-financed cash or in-kind programs targeted to the poor) protect the poor other than those financed by international agencies directed to refugees and victims of natural disasters.

Table 2 Djibouti: Net Remittances Share in Overall Expenditure, 1996

\begin{tabular}{|l|c|c|}
\hline Income Categories & All Djibouti & Rural \\
\hline All & 3.9 & 8.9 \\
poorest & & \\
2nd quartile & 7.7 & 9.0 \\
3rd quartile & 5.4 & 11.7 \\
richest & 2.8 & 7.1 \\
\hline
\end{tabular}

Note: Shares are expressed as a percentage of total household expenditure.

Source: Authors' calculation based on EDAM 1996 


\section{Estimating the Pass-Through Effect of a Nominal Exchange Rate Devaluation}

This section aims at estimating the exchange rate pass-through to domestic prices that would be necessary for the subsequent analysis of the social and fiscal impact of a nominal exchange rate devaluation.

Drawing on available time series data, the following equation is estimated: ${ }^{10}$

$$
\Delta p_{i t}=a_{i 0}+A_{i}(L) \Delta p_{i, t-1}+B_{i}(L) \Delta \text { neer }_{t}+C_{i}(L) \Delta p_{i t}^{*}+\varepsilon_{i t},
$$

where $p_{i t}$ is the log price index of good $i$, neer $r_{t}$ is the log effective nominal exchange rate and $p_{i t}^{*}$ is $\log$ effective foreign producer price index for good $i$ and $\varepsilon$ is the white noise disturbance term. The terms $A_{i}(L), B_{i}(L)$ and $C_{i}(L)$ denote lag polynomials. The effective foreign producer price is computed as arithmetic averages using trade weights ${ }^{11}$ :

$$
P_{i t}^{*}=\sum_{n=1}^{N} w_{n} P_{\text {int }}^{*},
$$

Where $P_{i t}^{*}$ is the effective foreign producer price index, $w_{n}$ is the average trade weight for Djibouti's main trading partners between 1995 and 1999, and $P_{\text {int }}^{*}$ is the producer price index of foreign country $n$ at time $t$.

The short-run exchange rate pass through elasticity is defined as the contemporaneous coefficient of $B_{i}(L)$ while the long-run elasticity is $B_{i}(L) /\left(1-A_{i}(L)\right)$. Thus a 1 percent nominal effective devaluation will result in an increase in relative prices of the good in question by $B_{i}(L) /\left(1-A_{i}(L)\right)$.

Due to data limitations, pass-through equations could not be estimated for all the tradable goods. For the purposes of this paper, a single pass-through equation is estimated on food prices using available using quarterly data from May 1999 to March $2005^{12}$. Food staples constitute the largest share in the CPI and in the average household budget. Food represents about 43 percent of overall household expenditure. The combined food and qhat share of an average household's budget makes up nearly four-fifths of the share of tradable goods in the overall household budget. Since data on qhat prices is unavailable, qhat is assumed to have the same pass-through elasticity as food.

\footnotetext{
${ }^{10}$ Adapted from Campa and Goldberg (2002)

${ }^{11}$ Foreign PPI were estimated for the following trading partners: France, Italy, United Kingdom, Thailand and Japan, drawing on data from WEO (2004).

12 Aggregated quarterly data is available from May 1999 to March 2005 on the following categories of items in the CPI: foodstuffs, drinks, tobaccos, clothing and shoes, housing, water, electricity, gas and other fuels, furnishing, domestic equipment and servicing house, health, transportation, leisure and culture activities, hotels, cafés and restaurants and other goods and services
} 
The empirical specification of the exchange rate pass-through on food prices entails running a regression of the log food price index, food $t$ on the log nominal effective exchange rate and log effective foreign producer price index (efppi). Model selection led to the following auto regressive specification ${ }^{13}$,

$$
\begin{aligned}
\Delta \text { food }_{t}= & 0.018+0.315 \Delta \text { food }_{t-4}+0.143 \Delta \text { neer }_{t-6}+ \\
(0.002)^{* * *}(0.101)^{* *} & (0.553)^{* *}
\end{aligned}
$$

The long-run elasticity for food turns out to be $\mathbf{0 . 5 9 ^ { 1 4 }}$. For the purposes of this paper, this elasticity is used to represent the exchange rate pass-through for all tradable goods. This passthrough estimate will be used in the subsequent analysis and as a test of sensitivity; the results are also reproduced assuming long-run NEER elasticities for tradable goods at 0.5 and 0.7 .

\section{Estimating the Fiscal Impact of a Nominal Exchange Rate Devaluation}

The aim of this section is to estimate the first order effect in the short-term of a nominal exchange rate devaluation in Djibouti. It first outlines the major channels through which currency devaluation is expected to influence the fiscal sector ${ }^{15}$. It then calculates the changes in real revenue and expenditure in response to a nominal exchange rate devaluation of 30 percent, using 2004 as a base year. As it will be illustrated, the magnitude of the short-term of the fiscal effect of the currency devaluation will depend on the size of the devaluation, the assumptions on exchange rate pass-through and whether or not the government introduces wage indexation.

\subsection{Fiscal Adjustment to Devaluation: Main Channels}

The first-order responses of real fiscal revenue and expenditure to changes in the real exchange rate are examined as follows.

\subsubsection{Revenue Effects}

In Djibouti, the main sources of government revenue are taxes, official grants and military-related revenues. Taxes are earned on imported goods (indirect taxes) and on wages, income and profits (direct taxes), which are assumed to mainly originate in the non-tradable sector such as the public sector. Real government revenue can be written as,

$$
R=\left(t_{n} P_{n} Y_{n}+t_{m} E \cdot M^{*}+E F^{*}\right) / P
$$

where $\mathrm{R}$ is real government revenue; $t_{n}$ and $t_{m}$ are the tax rates applied in the non-tradable sector and imports respectively, $E$ is the currency price of a unit of foreign exchange or the nominal exchange rate, $M^{*}$ is the foreign value of imports, $F^{*}$ is the flow of official grants and

\footnotetext{
${ }^{13}$ See full results in appendix, Table A.1.

${ }^{14}$ This estimates results from using the formula, $B(L) /(1-A(L))=(0.143+0.264) /(1-0.315)$.

${ }^{15}$ This section draws on Yiheyis (2000) and expands the fiscal framework to incorporate varying degrees of exchange pass-through and public wage-indexation.
} 
military aid in foreign currency; $P_{n}$ is the average price of non-trade goods and services which includes the public sector, $P^{*}$ is the foreign price level; and $P$ is the aggregate price level, which is $P_{n}^{\delta}\left(E P^{*}\right)^{1-\delta}$ where $\delta$ is the share of non-tradable goods and services in aggregate expenditure.

Assume that $\tilde{F}^{*}=t_{n}^{\prime}=t_{m}^{\prime}=\tilde{P}^{*}=0 \quad$ (where $(\sim)$ denotes growth rate) and note that $\tilde{P}=\delta \tilde{P}_{n}+(1-\delta) \tilde{E}$. In addition, the assumption of complete-pass through from the exchange rate to domestic prices of devaluation is relaxed and it is assumed that prices of nontradable goods and services are indexed to the nominal exchange rate, which is a way of indirectly reflecting public sector wage indexation ${ }^{16}$, i.e. $P_{n}=\left(E^{\tau}\right)^{\beta}$. Real government revenue can be rewritten as,

$$
R=\left(t_{n} P_{n} Y_{n}+t_{m} E M^{*}+E F^{*}\right) / P \text {, where } P=P_{n}^{\delta}\left(E^{\tau} P^{*}\right)^{1-\delta} \text { and } P_{n}=\left(E^{\tau}\right)^{\beta}
$$

and the revenue adjustment to devaluation takes the following form ${ }^{17}$,

$$
\widetilde{R}=\left\{(1-\tau+\delta \tau)\left(\eta_{f}+\eta_{m}\right)+(\beta-(1-\delta) \tau) \eta_{n}-\beta \tau \delta\right\} \tilde{E}+\left(\eta_{n} \tilde{Y}_{n}+\eta_{m} \tilde{M}^{*}\right)
$$

where $\eta_{m}, \eta_{f}$ and $\eta_{n}$ are the revenue shares of imported goods, grants and non-tradable goods and services respectively, $\tau \in[0,1]$ is the pass-through elasticity and $\beta \in[0,1]$ is the degree of wage indexation. Using the latest data for 2004, the corresponding revenue shares are $\eta_{m}=30.3 \%, \eta_{n}=32.2 \%, \eta_{f}=37.5 \%$. Hence revenue from foreign currency denominated grants and military aid constitutes the largest share.

In static terms, a nominal exchange rate devaluation in Djibouti could increase revenues through higher trade taxes by raising import value in terms of local currency. It could also have a positive impact on revenues deriving from foreign currency denominated grants. If public sector wages were indexed, nominal exchange rate devaluation would also contribute to higher income taxes. However, tax revenues from the import sector may fall if import demand declines with a devaluation $\left(\tilde{M}^{*}<0\right)$ implying that demand is price elastic ${ }^{18}$. At the same time, the overall price level could rise ${ }^{19}$ given Djibouti's high import content of overall consumption and may cause real revenues to decline if the increase in aggregate prices is higher than the gain in nominal revenue ${ }^{20}$.

\footnotetext{
${ }^{16}$ This is a reasonable assumption for Djibouti considering the relatively large size of the public services in the formal non-tradable sector.

${ }^{17}$ See appendix for a fuller derivation of this expression.

${ }^{18}$ In addition, if a currency devaluation is contractionary in the non-tradable sector $\left(\tilde{Y}_{n}<0\right)$, tax revenues would also fall.

${ }^{19}$ The magnitude of the overall increase in domestic prices will be dependent on the degree of exchange rate passthrough

${ }^{20}$ For the purposes of the paper, the growth rate of imports is assumed to remain unaffected by the nominal exchange rate devaluation.
} 
Based on a nominal devaluation of $30 \%$, a pass-through of $60 \%$ and indexation of $30 \%$, the resulting growth rate of real revenue is $\mathbf{7 . 8 6 \%}$. This can be divided between nominal revenue rising by $22.08 \%$ and aggregate price level increases by $14.22 \%$, with the resulting real growth rate reflecting the difference. The resulting real revenue level is

$$
R_{\text {new }}=(1+\tilde{R}) R_{\text {old }} \text {. }
$$

Real revenue (deflated by the GDP deflator with 2004 as the base year) was DF 41.5 billion in 2004 . With a growth rate of $7.86 \%$ in lieu of a $30 \%$ devaluation, the new expected level of real government revenues is DF 44.5 billion.

\subsubsection{Expenditure Effects}

Government expenditure is assumed to be on tradable and non-tradable goods and services, and on interest payments on domestic and external debt. In Djibouti, government expenditures on non-tradables (wages and salaries) absorb about half of total expenditure. For the purposes of this paper, capital expenditure, materials and supplies are assumed to be imported, and therefore are considered as expenditures on tradable goods.

Real government expenditure can be expressed as,

$$
G=\left(P_{n} G_{n}+E G_{m}^{*}+i^{*} E \cdot E X D_{-1}\right) / P
$$

where $G$ is real government expenditure, $G_{n}$ is real government expenditure on non-tradable goods and services as measured in units of non-tradable goods, $G_{m}$ is the foreign value of government expenditure on imported goods and $E X D_{-1}$ is the external debt owned by the public sector at the end of the previous period; $i^{*}$ is the foreign interest rate and other variables are defined as before. Again, incorporating public wage indexation and the possibility of incomplete pass-through, real government expenditure can be rewritten as,

$$
G=\left(P_{n} G_{n}+E^{\tau} G_{m}^{*}+i^{*} E \cdot E X D_{-1}\right) / P \text {, and } P_{n}=\left(E^{\tau}\right)^{\beta}
$$

Assuming that external debt will be maintained constant, the adjustment of real government expenditure to devaluation can be expressed $\mathrm{as}^{21}$ :

$$
\tilde{G}=\left\{\delta \tau \varphi_{m}+(1-\tau+\tau \delta) \varphi_{\text {exd }}+(\beta-1+\delta) \tau \varphi_{n}-\beta \tau \delta\right\} \tilde{E}+\left(\varphi_{n} \tilde{G}_{n}+\varphi_{m} \tau \tilde{G}_{m}\right),
$$

where $\varphi_{m}, \varphi_{n}$ and $\varphi_{\text {exd }}$ denote respectively, the expenditure shares on tradable goods, nontradable $^{22}$ goods and interest payments on external debt; $\tau \in[0,1]$ is the pass-through elasticity

\footnotetext{
${ }^{21}$ See appendix for a fuller derivation of this expression

${ }^{22}$ Non-tradable expenditure items are wages and salaries and transfers. All other expenditure items except for interest payments are classified as tradables. Maintenance expenses were treated as tradables due to the higher likelihood of expatriate services involved.
} 
and $\beta \in[0,1]$ is the degree of indexation as defined earlier. The expenditure shares in 2004 were according, $\varphi_{m}=48.1 \%, \varphi_{n}=50.6 \%, \varphi_{\text {exd }}=1.3 \%$.

The short-term impact of a nominal exchange rate devaluation is expected to be an increase on government expenditure on tradable goods and services and on interest payments (added expenditure associated to the local currency cost of foreign debt servicing ${ }^{23}$. At the same time, to the extent that currency devaluation raises the aggregate price level, it would lower real wages, which is the main component of Djibouti's' government expenditure. A nominal exchange rate devaluation could also affect government spending if it causes a change in discretionary fiscal policy such as raising salaries of public sector employees to protect their real earnings from a devaluation-induced rise in prices of consumption goods, a policy which can be reflected by an additional increase in government expenditure on non-tradable services. For the purposes of this paper, this possibility is captured in the wage indexation method outlined in the discussion on revenue, where the growth rate of the price of non-tradable goods, $\widetilde{P}_{n}=\beta \tau \widetilde{E}$.

Based on a nominal devaluation of $30 \%$, a pass-through of $60 \%$ and indexation of $30 \%$, the resulting growth rate of real government expenditure is $-2.43 \%$. This can be divided between nominal expenditure rising by $11.79 \%$ and aggregate price level increases by $14.22 \%$, with the resulting real growth rate reflecting the difference. The resulting real expenditure level is

$$
G_{\text {new }}=(1+\tilde{G}) G_{\text {old }} \text {. }
$$

Real expenditure (deflated by the GDP deflator with 2004 as the base year) was DF 40.1 billion in 2004 . With a growth rate of $-2.43 \%$ in lieu of a $30 \%$ devaluation, the new expected level of real government expenditure is DF 39.1 billion.

\subsubsection{Estimating the Real Fiscal Savings from a Nominal Exchange Rate Devaluation}

In early 2005 which is the base year for the purposes of the analysis, real fiscal savings was DF 1.37 billion or $1.16 \%$ of GDP. The predicted levels of real fiscal savings after a $30 \%$ devaluation with $60 \%$ pass through, assuming no indexation, which is equation (8) less equation (11), is DF 6.61 billion or $4.6 \%$ of $\mathrm{GDP}^{24}$. Tables 3 summarizes estimates of fiscal savings under a matrix of $30 \%, 60 \%$ and $100 \%$ devaluation assuming $0 \%$ and $30 \%$ wage indexation.

Table 3 Djibouti: Gross Fiscal Savings From various Devaluation Scenarios (DF bn/percent of GDP)

\begin{tabular}{|c|c|c|c|c|c|c|c|c|}
\hline \multirow{2}{*}{$\begin{array}{c}\text { Devaluation } \\
\text { Rate }\end{array}$} & \multicolumn{2}{|c|}{ 50\% pass-through } & \multicolumn{2}{|c|}{$60 \%$ pass-through } & \multicolumn{2}{|c|}{$70 \%$ pass-through } & \multicolumn{2}{|c|}{$100 \%$ pass-through } \\
\hline & $\begin{array}{c}0 \% \\
\text { Indexation }\end{array}$ & $\begin{array}{c}30 \% \\
\text { Indexation }\end{array}$ & $\begin{array}{c}0 \% \\
\text { Indexation }\end{array}$ & $\begin{array}{c}30 \% \\
\text { Indexation }\end{array}$ & $\begin{array}{c}0 \% \\
\text { Indexation }\end{array}$ & $\begin{array}{c}30 \% \\
\text { Indexation }\end{array}$ & $\begin{array}{c}0 \% \\
\text { Indexation }\end{array}$ & $\begin{array}{c}30 \% \\
\text { Indexation }\end{array}$ \\
\hline $30.0 \%$ & 6.61 & 6.28 & 6.00 & 5.61 & 5.40 & 4.93 & 3.57 & 2.91 \\
\hline$\%$ of GDP'05 & $5.40 \%$ & $5.13 \%$ & $4.90 \%$ & $4.58 \%$ & $4.41 \%$ & $4.03 \%$ & $2.92 \%$ & $2.38 \%$ \\
\hline $60.0 \%$ & 11.85 & 11.19 & 10.64 & 9.84 & 9.42 & 8.50 & 5.78 & 4.45 \\
\hline$\%$ of GDP'05 & $9.68 \%$ & $9.14 \%$ & $8.69 \%$ & $8.04 \%$ & $7.70 \%$ & $6.94 \%$ & $4.72 \%$ & $3.64 \%$ \\
\hline $100.0 \%$ & 18.84 & 17.73 & 16.81 & 15.49 & 14.79 & 13.24 & 8.71 & 6.51 \\
\hline$\%$ of GDP'05 & $15.39 \%$ & $14.49 \%$ & $13.73 \%$ & $12.65 \%$ & $12.08 \%$ & $10.82 \%$ & $7.12 \%$ & $5.32 \%$ \\
\hline
\end{tabular}

Note: Values are in constant Djibouti Franc terms with the base year of 2004.

Source: Authors' calculation based on EDAM 1996

${ }^{23}$ In Djibouti, only a small fraction of government expenditure (0.5\%) goes to service external debt.

${ }^{24}$ This is expressed as a share of predicted GDP in 2005 which is estimated by the WEO at DF 122.4 billion. 
Figure 6 graphically displays a convex relationship between the degree of devaluation and real fiscal gain as a share of GDP under different pass-through and indexation scenarios. The higher the degree of devaluation, the larger the real fiscal gains in local currency terms. Larger pass-through elasticities also raise the fiscal space generated in real terms, though the presence of wage indexation in the public sector will dampen the increase.

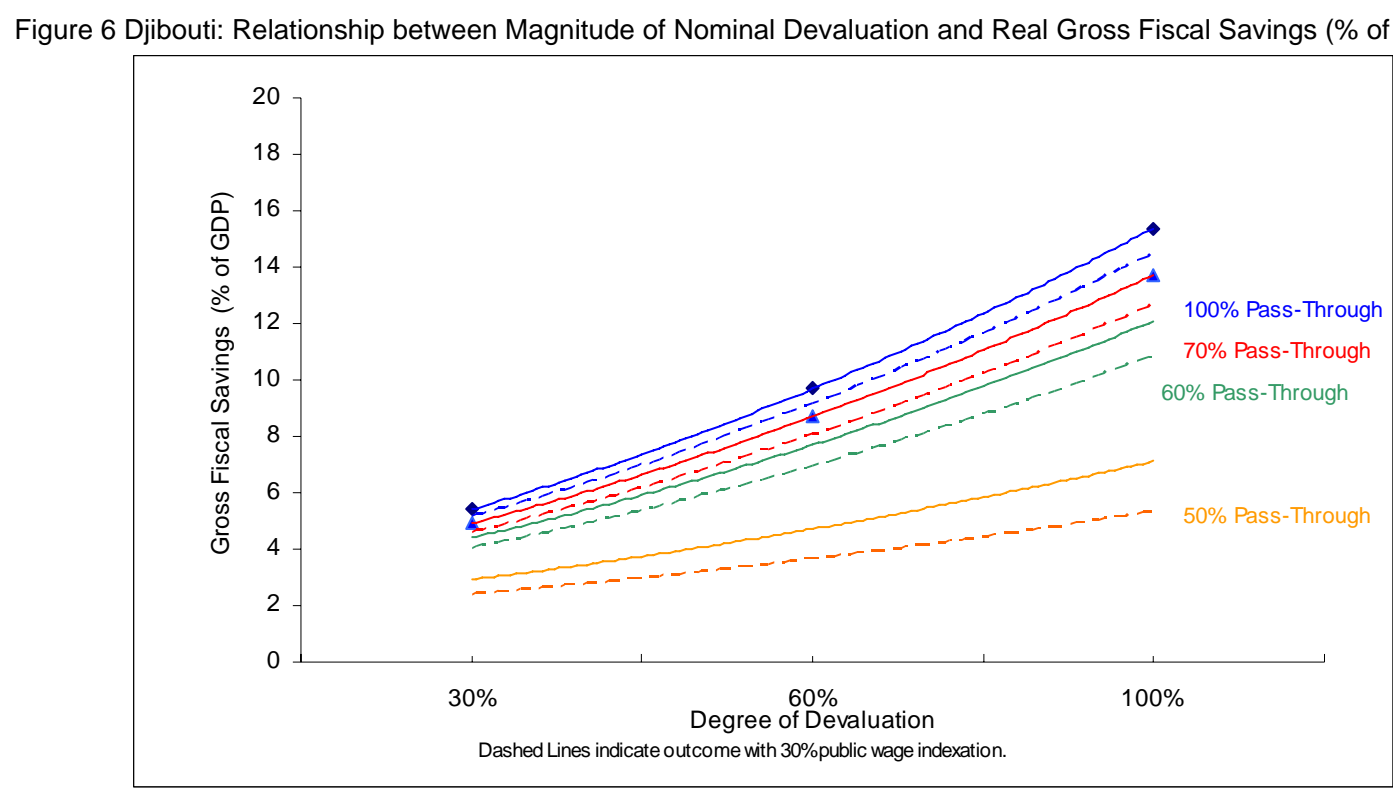

Source: Authors' calculation based on CPI data and WEO 2004.

\section{Social Impact of a Nominal Exchange Rate Devaluation}

The purpose of this section is to examine the impact of a potential nominal exchange rate devaluation of the Djibouti Franc on poverty, income distribution and real wages. Using sampling weights from the household survey, it estimates the real income loss that a Djibouti household would on average incur, as a result of a nominal exchange rate devaluation. It moves on to estimate the potential fiscal costs in the form of social transfers that would be needed to compensate the population for the real income loss engendered by a nominal exchange rate devaluation. It also estimates the impact of a currency devaluation on the incidence and depth of poverty as well as its distributional impact. (through predicted changes in consumer prices and wage income) using a simple model of rural/urban households whose members are primarily wage earners. The section ends with an estimation of the impact of a nominal exchange rate devaluation on real wages.

\subsection{Methodology}

Three steps are needed in order to determine the distributional and poverty effects of devaluation:

1. Determine expenditure shares of tradable and non-tradable goods and services including wage income from Djibouti’s representative household survey conducted in 1996;

2. Using historical data on exchange rates, domestic and world prices to estimate the impact of a nominal devaluation on prices in Djibouti; 
3. Simulate the effect of devaluation on income distribution and poverty, by tracing the impact on the structure of prices and subsequently on real income, proxied by household expenditure.

To motivate the empirical work, consider a household's indirect utility function, $v(\boldsymbol{p}, y)$ expressed as a function of prices, $\boldsymbol{p}$ and household income, $y$. Income is derived from the sum of wages earned across household members, wl and self-employment. Though Djibouti maintains a currency board with the Djibouti France pegged to the US dollar, movements in other currencies relative to the dollar renders the use of the nominal effective exchange rate (NEER) more appropriate, which can be defined as trade weighted share of bilateral exchange rates with Djibouti's major trading partners.

Consider only first order effects ${ }^{25}$, therefore the change in household utility in response to changes in devaluation induced prices is:

$$
d u_{h}=\sum_{i} \frac{\partial v_{h}}{\partial p_{i}} d p_{i}+\frac{\partial v_{h}}{\partial y_{h}} d y_{h}
$$

Assume that the marginal utility of income, $\partial v / \partial y=1$, and apply Roy's Identity, $\partial v / \partial p_{i} / \partial v / \partial y=-c_{i}$, where $c_{i}$ is the quantity consumed of good $i$. Suppressing the subscripts for household, $h$, equation (1) can be rewritten as;

$$
d u=d y-\sum_{i} c_{i} d p_{i}
$$

Now, $d y=\sum_{m} l_{m} d w_{m}$ where $l_{m}$ is the labor supply of individual member $m$ of household, h who earn wage income. Dividing through by initial household income (or expenditure as a proxy), equation (10) becomes,

$$
\begin{gathered}
\frac{d u}{y}=\sum_{m} \theta_{m}^{w} \frac{d w_{m}}{w_{m}}-\sum \theta_{i}^{c} \frac{d p_{i}}{p_{i}}, \text { or in discrete terms, } \\
\frac{\Delta W}{y_{0}}=\sum_{m} \theta_{m}^{w} \tilde{w}_{m}-\sum_{i} \theta_{i}^{c} \tilde{p}_{i}
\end{gathered}
$$

where $\theta_{m}^{w}=w_{m} l_{m} / y$ is the contribution of wages to total income of member $m$ of household $h$, $\theta_{i}^{c}$ is the share of household expenditure spent on good $i$ and $\tilde{x}=\Delta x / x$, the percentage change

\footnotetext{
${ }^{25}$ Second order effects which incorporate behavioral responses by consumers could not be considered due to data limitations. However, most studies looking at consumption behavior do indicate a large difference between first and second order effects. We treat the first-order effects estimated in this study as an upper bound to the welfare cost of devaluation.
} 
in variable $x^{26}$. The change in welfare or real income as a percentage of initial income in response to a change in the nominal effective exchange rate, can be divided into income and consumption effects. On the income side, household's income will be affected by how wages respond to movements in the NEER. On the consumption side, the household's budget exposure to goods that are tradable will determine the cost of devaluation ${ }^{27}$.

To compute the welfare measure, income and budget shares can be obtained from the household survey. What remains are to determine how wages and consumer prices respond to changes in the NEER. Assume that the pass-through coefficient is $\tau \in[0,1]$ and $\tilde{E}$ is the percentage increase in the nominal exchange rate (a devaluation), then the percentage change in price, $\tilde{p}$ in response to a devaluation is

$$
\tilde{p}=\tau \tilde{E}
$$

If there exist some degree of public wage indexation captured by the parameter, $\beta \in[0,1]$, then the percentage change in public sector wages, $\widetilde{w}$ is given by,

$$
\widetilde{w}_{p u b}=\beta \tilde{p}
$$

\subsection{Main Assumptions}

For illustrative purposes, we present results for a nominal exchange rate devaluation of 30 percent and with no wage indexation. Subsequently, we will determine the expected real income loss to poor households in the population ${ }^{28}$ under various exchange rate and wage indexation scenarios. To simulate the effect of a 30 percent nominal Djibouti franc devaluation, the following assumptions are made:

(i) Tradable goods consist of food (excluding bread and crepe), tobacco, qhat, school supplies, clothing and medical drugs while non-tradable goods and services are water and electric expenses, rent, health services and transportation;

(ii) Assuming a long-run elasticity of 0.6 for tradable goods, a 30 percent nominal devaluation translates into an 18 percent increase for tradable prices. For sensitivity analysis, this exercise is repeated assuming 0.5 and 0.7 long-run NEER elasticity for tradable goods;

(iii) Holding nominal wages fixed, the impact of a real devaluation is felt in terms of a decline in purchasing power or real income across households.

Three scenarios are considered, using a pass-through elasticity of $0.5,0.6$ and 0.7 for tradable goods which correspond to scenario one, two and three respectively. The higher the degree of exchange rate pass-through to domestic prices of tradable goods, the larger the resulting real income loss for the population of Djibouti.

\footnotetext{
${ }^{26}$ If price data is available for 1996, second-order effects for consumption could be included. Equation (3) would then take the form $\frac{\Delta W}{y_{0}}=\sum_{m} \theta_{m}^{w} \tilde{w}_{m}-\left(\sum_{i} \theta_{i}^{c} \tilde{p}_{i}+\frac{1}{2} \theta_{i}^{c} \eta_{i} \tilde{p}_{i}^{2}\right)$ where $\eta_{i}$ is the compensated own price elasticity for good $i$.

${ }^{27}$ All services are assumed to be non-tradable.

${ }^{28}$ The household survey used for the analysis is EDAM 1996, which surveys 2380 households from the sedentary population in 1996. The survey consists of a household and individual questionnaire. Questions are asked on household expenditures and migration and individual level income, education attainment and health status.
} 
The social impact of a nominal devaluation on households can be examined from the perspective of real income losses, changes in poverty incidence and variations in income distribution.

\subsection{Average Household Real Income Loss}

Table 4 estimates the average household real income loss as a result of a nominal exchange rate devaluation. It presents the results based on equation (11) holding nominal wages fixed, while allowing the price of tradable goods to vary in response to a hypothetical nominal devaluation of 30 percent under different pass-through scenarios. The scenarios are titled first, second and third which corresponds to a long-run exchange rate elasticity of 50 percent, 60 percent and 70 percent, respectively.

Table 4 Djibouti: Welfare Cost of a $30 \%$ Nominal Devaluation

\begin{tabular}{|l|c|c|c|}
\hline \multirow{2}{*}{ Household Category } & \multicolumn{3}{|c|}{ \% Decline in Real Income } \\
\cline { 2 - 4 } Djibouti & 1st Scenario & 2nd Scenario & 3rd Scenario \\
Location & 9.9 & 11.9 & 13.9 \\
$\quad$ Urban & & & \\
$\quad$ Rural & 9.5 & 11.4 & 13.4 \\
& 11.9 & 14.3 & 16.7 \\
Income group & & & \\
$\quad$ Poorest & 11.4 & 13.7 & 16.0 \\
$\quad$ 2nd quartile & 10.1 & 12.2 & 14.2 \\
$\quad$ 3rd quartile & 9.6 & 11.5 & 13.4 \\
$\quad$ Richest & 8.6 & 10.3 & 12.0 \\
\hline Note: The decline in real income is expressed as a percentage of initial household \\
expenditure. \\
1st, 2nd and 3rd scenarios corresponds to using a long-run elasticity of traded goods \\
prices to the nominal exchange rate of $0.5,0.6$ and 0.7 respectively. \\
Source: Authors' calculation based on EDAM 1996
\end{tabular}

Using a 30 percent nominal devaluation and 60 percent pass-through (Scenario 2), Djibouti households would experience on average a real income loss of about 12 percent. This average figure does not however, capture the variation or extent of real income by households across the income distribution, proxied by per-capita expenditure. This is shown graphically in Figures 7 and 8 below using the outcomes under Scenario 2. Most Djibouti households are concentrated in the middle-income range, as indicated by peak of the 'cone' in Figure 7 and are expected to face a loss between 11 and 13 percent of their initial real income.
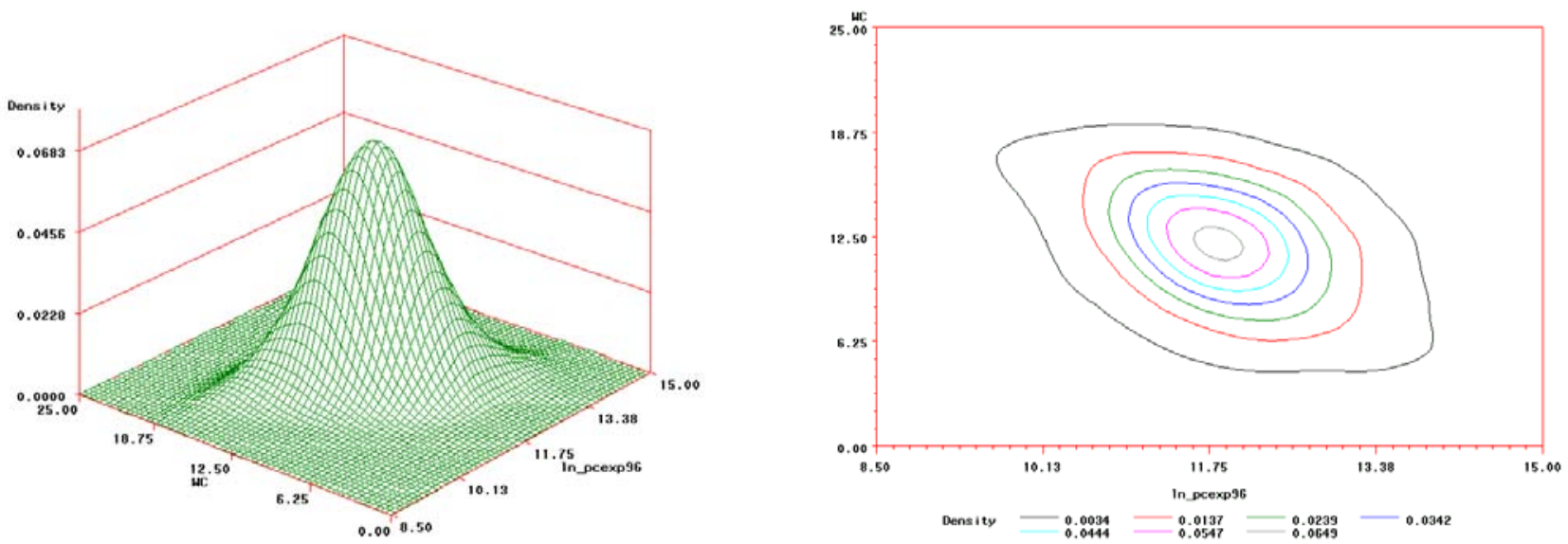
Looking further, the negative impact of the currency devaluation on real income varies according to gender, location and income group:

- $\quad$ Rural households bear a larger real income loss, estimated at about 14 percent of real income on average compared to 11 percent decline for urban households.

- Male and female headed households face similar costs, around 12 percent of real income on average.

- Households whose main source of labor income is derived from the tertiary sector (public administration, commerce, transportation) bear similar real income loss, estimated at about 12 percent on average.

- $\quad$ Poor households will also be worse off relative to their richer counterparts. Households in the lowest income group ( $25^{\text {th }}$ percentile) will experience a 14 percent drop in their real income on average compared to 10 percent decline for the richest households.

- $\quad$ Consumption of qhat raises the real income loss to richer groups. The small difference between share of real income loss between the poorest and richest groups is due to the larger share of qhat consumption in richer households in their overall expenditure. Table 5 shows that if only the pass-through effect is considered for food items, the poorest share of real income loss is about 1.4 times larger compared to the richest group. However once qhat is added as per the final column, the difference in real income loss narrows between the two groups.

Table 5: Real Income Loss as a share of Total Expenditure with $60 \%$ pass through
\begin{tabular}{|l|r|r|r|}
\hline Income Categories & $\begin{array}{c}\text { overall } \\
\text { welfare cost }\end{array}$ & $\begin{array}{c}\text { welfare cost } \\
\text { with food only }\end{array}$ & $\begin{array}{c}\text { welfare cost with } \\
\text { food \& qhat }\end{array}$ \\
\hline All & 11.9 & 8.4 & 10.1 \\
poorest & 13.7 & 11.3 & 11.9 \\
2nd quartile & 12.2 & 8.9 & 10.3 \\
3rd quartile & 11.5 & 7.5 & 9.7 \\
riches & 10.3 & 5.9 & 8.5 \\
\hline
\end{tabular}
Source: Author's calculation based on EDAM 1996.

\subsection{Impact on poverty ${ }^{29}$}

The incidence of extreme and national ${ }^{30}$ poverty will rise by 4.4 and 6.3 percentage points respectively while the poverty gap $^{31}$ is expected to increase by 1.3 (extreme) and 3.0 (national) percentage points respectively for the population. Figure 9 shows leftward shifts in the income distribution of households associated with greater magnitudes of nominal exchange rate devaluation, assuming a pass-through of 60 percent. The vertical height measures the density or concentration of households where prior to the devaluation (using the distribution of households in 1996), most households were located between the extreme and national poverty lines. As the size of the nominal exchange rate devaluation increases, a greater number of households would

\footnotetext{
${ }^{29}$ This section reports the poverty impact of a nominal devaluation of the magnitude of 30 percent assuming an exchange rate pass-through of 60 percent.

${ }^{30}$ Extreme poverty line is 100,229 FDJ (US\$566) per adult equivalent or US\$ 1.5 per adult per day. The national poverty line includes food and non-food consumption, is equivalent to 216,450 FDJ (US\$1,223) year or US\$ 3.3 per adult per day.

${ }^{31}$ The poverty gap (or the depth of poverty) measures how far below is poor households' per capita income from the poverty line. It is expressed as a share of the poverty line.
} 
fall below the extreme poverty line. Given Djibouti's already high rates of poverty incidence, the diagram illustrates the detrimental impact of a nominal devaluation exchange on the poor in the absence of social transfers that would offset the real income loss experienced by households hurt by the currency devaluation.

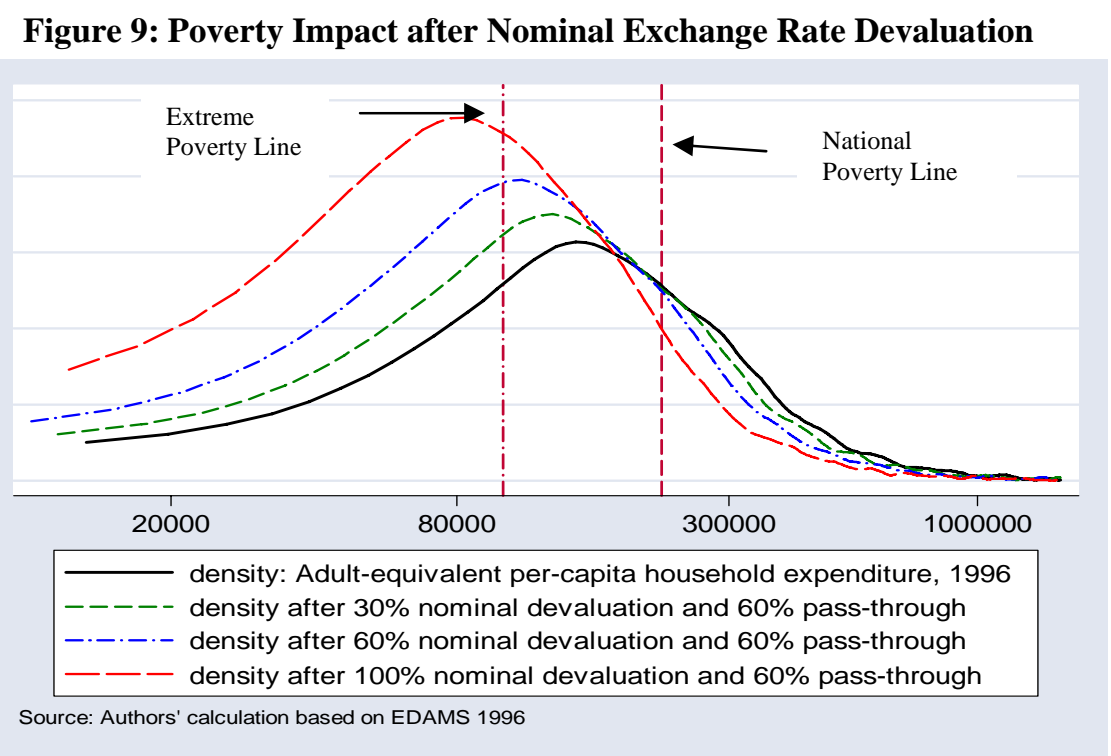

The negative poverty impact of a currency devaluation varies according to the location of the household, the gender of the head of the household, the income group to which the household belongs, and to the household's main source of labor income:

\section{- $\quad$ Rural households would experience larger declines in extreme poverty relative to urban households.}

- $\quad 17.5$ percent of households in the lowest consumption quartile would fall below the extreme poverty line and about 20.2 percent of middle-income households in the $3^{\text {rd }}$ quartile will drop below the national poverty line. Looking by income groups, 20.4 percent of middleincome households in the $3^{\text {rd }}$ quartile where commerce as the main wage income sources fall below the national poverty line, followed by 18.4 percent of households in the same income group whose main source of wage income is in public administration.

- $\quad$ The highest increase in extreme poverty would be experienced by households whose main wage source is from commerce (6.5 percentage points) followed by public administration (6.1 percentage points).Tables $\mathrm{A} .2 \mathrm{~b}$ and $\mathrm{A} .2 \mathrm{~d}$ of the appendix provide the outcomes on headcount poverty and the poverty gap by households whose main source ${ }^{32}$ of wage income is derived from the four largest sectors: public administration, services (excluding financial), commerce and transport and telecommunications. The incidence of extreme poverty is predicted to rise the most, by 7.6 percentage points for households whose main wage income source is from services. In terms of the national poverty line, the highest increase is from households whose main wage source is from commerce (6.5 percentage points) followed by public administration (6.1 percentage points).

\footnotetext{
${ }^{32}$ The sector which is considered the main source of wage income contributes over 90 percent to the overall wage income for a household.
} 
- In terms of the poverty gap it appears that households whose main wage earnings are from the transport and telecommunication sector experiences the largest fall away from both poverty lines. See table A.2d of the appendix.

- $\quad 18.7$ percent of the poorest households headed by men would fall below the extreme poverty line, compared to 14.2 percent of the poorest households headed by women. In absolute terms, the incidence of poverty among the poorest households, i.e those in the first quartile, is higher among female headed households relative to their male counterparts, though this gap narrows, the greater the degree of exchange rate pass-through (Tables A.2a and A.2c of the appendix).

- $\quad 20.7 \%$ of male headed households in the $3^{\text {rd }}$ quartile fall below the national poverty line compared to $18.3 \%$ of female headed households. Male headed households are adversely affected more than female headed households due to the larger budget share of qhat consumption among male headed households across all income groups. On average male headed households's share of qhat in overall expenditure is 10.9 percent compared to 4.7 percent for female headed households as seen in Table 6 . This share reaches the highest among the richest strata of male headed households with nearly 16 percent of the total expenditure devoted to qhat.

Table 6: Qhat consumption as a share of total expenditure (\%)
\begin{tabular}{|l|c|c|c|}
\hline \multirow{2}{*}{ Income Categories } & All & Mouseholds Head & Female Head \\
\cline { 2 - 4 } & 9.5 & 10.9 & 4.7 \\
All & & & \\
poorest & 3.5 & 4.4 & 1.1 \\
2nd quartile & 7.5 & 8.9 & 3.5 \\
3rd quartile & 12.2 & 13.3 & 8.2 \\
richest & 14.7 & 15.9 & 8.1 \\
\hline
\end{tabular}

Source: Authors' calculation based on EDAM 1996

\subsection{Impact on income distribution}

Income inequality as measured by the Gini index rose slightly across all three scenarios which tentatively show that the devaluation exercise will not exacerbate inequality. Again this appears to be due to the greater budget share of qhat consumption among the richer segment of the society where higher cost due to the devaluation causes a flattening of the post-devaluation income distribution.

\subsection{Impact on real wages}

In the absence of wage indexation, nominal exchange rate devaluation will result in falling real public sector wages. With a pass-through elasticity of 60 percent, a 30 percent nominal devaluation will cause real public sector wages to fall by 12.6 percent. The higher the passthrough elasticity and magnitude of devaluation, the greater the fall in real public sector wages as in shown in the Appendix Tables A.6 to A.8. However, if the authorities decide to apply a 30 percent wage indexation, as it was the case in the past, it will offset the decline in real wages engendered by the nominal exchange rate devaluation. It may even lead to a net increase in real public sector wages. For example, under the scenario of 30 percent nominal exchange rate 
devaluation and a 60 percent pass-through, a 30 percent indexation of public wages will cause real public sector wages to rise by 1.6 percent.

\section{Estimating Fiscal Savings Net of Social Transfers}

\subsection{Costing out Social Transfers}

As the foregoing analysis shows, a nominal exchange rate devaluation will adversely affect households, particularly the poor since most of their expenditure is on tradable goods (food and qhat ${ }^{33}$. This section aims to estimate the value of fiscal transfers needed to compensate the poor (including those households that would fall below the national poverty line after the devaluation and those poor households that experienced a real income loss as a result of the devaluation).

\subsubsection{Methodology and Main Assumptions}

First, the results regarding the average real income loss to the Djibouti population presented in the previous section (based on sample data from the EDAM 1996 household survey) are extrapolated to the total population. To arrive at the total cost for the (sedentary) population, it is first assumed that for each location sampled, the same proportion of (sedentary) households that are poor in the sample also holds true for the population. This implicitly means that the income distribution in the household survey sample is the same for the population. The survey design provides the number of households in the population for each location in 1996 (for example, see Table A.3a). Sample weights, which vary by location, can be determined from the ratio of households in the population to the 1996 sample.

A growth rate of 3 percent per year is used to estimate the number of households in the population in 2005. The resulting new sample weights are broadly, 25.7 for Djibouti-ville, 15.3 for other urban areas and 8.5 for rural areas. These weights are multiplied with the real income loss for the sample of poor households for each respective location to derive the cost to poor households in the population under various scenarios of wage indexation ${ }^{34}$ and degrees of nominal exchange rate devaluation. The total real income loss of a nominal exchange rate devaluation is estimated by summing across locations. This is assumed to be the value of social transfers that the government can anticipate to compensate the affected population for their welfare loss.

\subsubsection{Costing out the social transfers needed to compensate the poor for their real income loss}

Assuming a pass-through elasticity of $60 \%$ and no wage indexation, a $30 \%, 60 \%$ and $100 \%$ nominal devaluation will result in a cost of DF 2.44 billion, 6.29 billion and 14.54 billion respectively in social transfers needed to compensate the poor. This is equivalent to $2 \%, 5.14 \%$ and $11.88 \%$ of GDP respectively. As expected, the cost of social transfers increases with higher degrees of devaluation and pass-through elasticity. The results are presented in Tables A.3 to A.5 of the appendix. Figure 10 graphically displays what appears to be a convex relationship between

\footnotetext{
${ }^{33}$ Some of the loss may be mitigated by higher nominal wages for households with members working in the public sector if the government decides to index wages. Naturally, not all households will benefit from the indexation of public wages. For our purpose, only households where the share of annual income earned from the public sector exceeding $90 \%$ of total income are assumed to have their wages indexed. These households represent $65 \%$ of the total households in the sample.

${ }^{34}$ Only households where the share of annual labor income from the public sector exceeding 0.9 have wages indexed.
} 
the degree of devaluation and real income loss as a share of GDP to households falling below the national poverty line under different pass-through and wage indexation assumption. The higher the pass-through, the higher the real income loss (though indexation helps to lower losses for a given devaluation rate as can be seen from the dashed lines which traces the real income loss associated with a $30 \%$ public wage indexation). The real income loss also rises at an increasing rate, the greater the degree of devaluation.

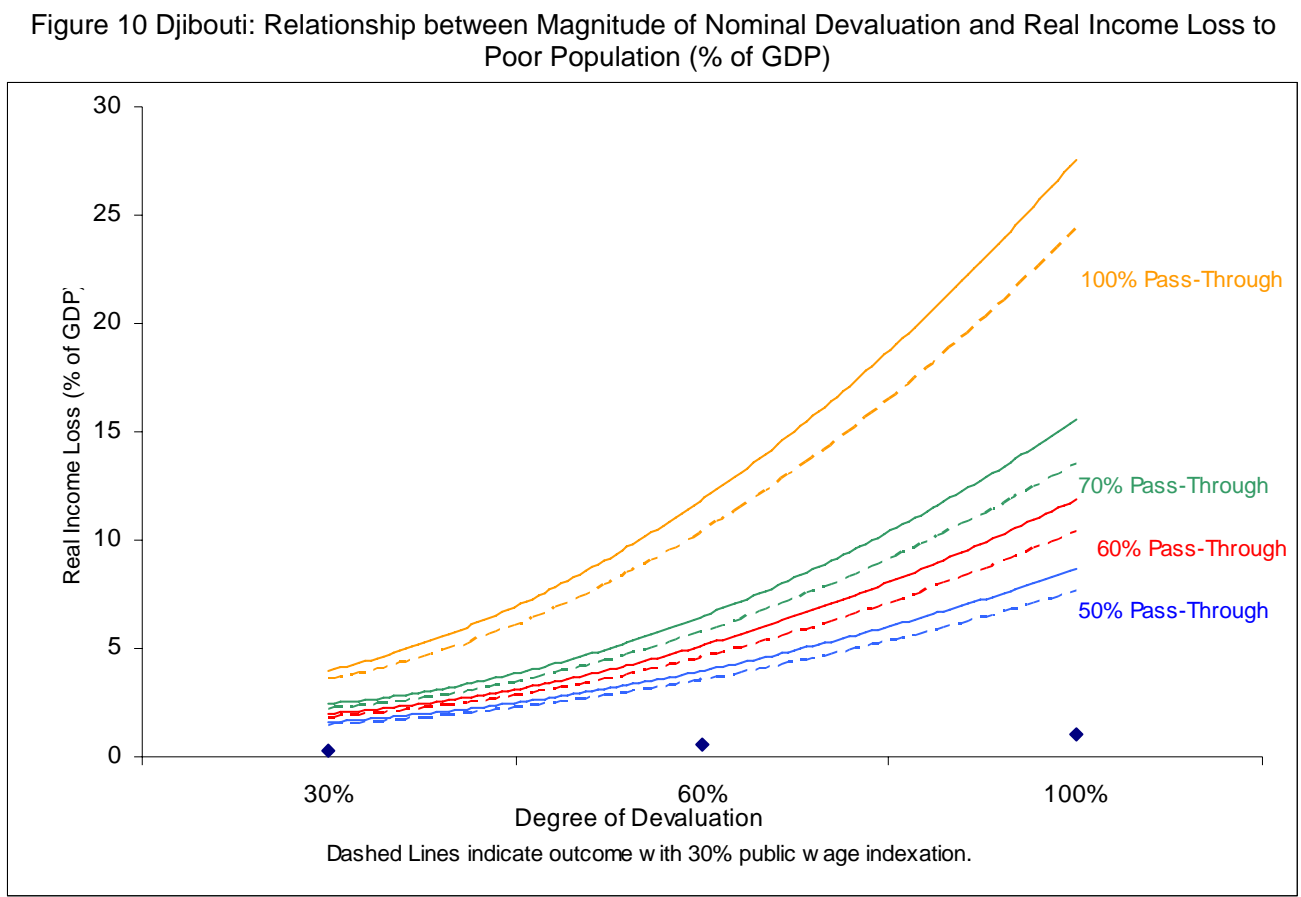

Source: Authors' calculation based on WEO, 2004

\subsection{Estimating Fiscal Savings Net of Social Transfers}

Can the Djibouti authorities compensate the poor for their real income loss in the form of social transfers and still be left with a positive level of fiscal savings? The previous discussion has shown that there will be real income losses to the population in response to a nominal exchange rate devaluation, with the poorer segments being particularly hurt. This section estimates the real fiscal savings that could be generated by a currency devaluation after having accounted for the amount of social transfers needed to compensate its poor population for its real income loss.

\subsubsection{Methodology and Main Assumptions}

Two scenarios are considered. A first scenario assuming no wage indexation and a second scenario assuming a 30\% wage indexation. The analysis is further disaggregated according to four possible exchange rate pass-through $(50 \%, 60 \%, 70 \%$ and $100 \%)$. A summary of the results is shown below in Table 7 (see also Tables A.6 to A.8 of the appendix). 


\subsubsection{Fiscal savings of a nominal exchange rate devaluation net of social transfers}

A 30 percent nominal devaluation with exchange rate pass-through elasticity of 60 percent and no wage indexation could generate a net fiscal savings of DF 4.35 billion, equivalent to 3.6 percent of GDP. Incorporating a 30 percent public sector wage indexation reduces the net savings to 4.25 percent of GDP. As the degree of pass-through rises, the level of net fiscal savings falls rapidly and turns negative due to the expansion in the cost of social transfers. With a 100 percent exchange rate pass-through, the amount of fiscal savings needed to cover social transfers fall short of DF 8.8 billion or 7.2 percent of GDP.

Table 7 Djibouti: Real Fiscal Savings Net of Social Transfers Scenarios (DF bnl/percent of GDP)

\begin{tabular}{|c|c|c|c|c|c|c|c|c|}
\hline \multirow{2}{*}{$\begin{array}{c}\text { Devaluation } \\
\text { Rate }\end{array}$} & \multicolumn{2}{|c|}{ 50\% pass-through } & \multicolumn{2}{|c|}{$60 \%$ pass-through } & \multicolumn{2}{|c|}{ 70\% pass-through } & \multicolumn{2}{|c|}{ 100\% pass-through } \\
\hline & $\begin{array}{c}0 \% \\
\text { Indexation }\end{array}$ & $\begin{array}{c}30 \% \\
\text { Indexation }\end{array}$ & $\begin{array}{c}0 \% \\
\text { Indexation }\end{array}$ & $\begin{array}{c}30 \% \\
\text { Indexation }\end{array}$ & $\begin{array}{c}0 \% \\
\text { Indexation }\end{array}$ & $\begin{array}{c}30 \% \\
\text { Indexation }\end{array}$ & $\begin{array}{c}0 \% \\
\text { Indexation }\end{array}$ & $\begin{array}{c}30 \% \\
\text { Indexation }\end{array}$ \\
\hline $30.0 \%$ & 4.65 & 4.50 & 3.56 & 3.39 & 2.40 & 2.24 & -1.29 & -1.42 \\
\hline \% of GDP'05 & $3.80 \%$ & $3.67 \%$ & $2.91 \%$ & $2.77 \%$ & $1.96 \%$ & $1.83 \%$ & $-1.05 \%$ & $-1.16 \%$ \\
\hline $60.0 \%$ & 6.99 & 6.86 & 4.35 & 4.25 & 1.48 & 1.45 & -8.76 & -8.25 \\
\hline$\%$ of GDP'05 & $5.71 \%$ & $5.60 \%$ & $3.55 \%$ & $3.47 \%$ & $1.21 \%$ & $1.19 \%$ & $-7.16 \%$ & $-6.74 \%$ \\
\hline $100.0 \%$ & 8.26 & 8.41 & 2.27 & 2.78 & -4.23 & -3.30 & -25.02 & -23.24 \\
\hline$\%$ of GDP'05 & $6.75 \%$ & $6.87 \%$ & $1.86 \%$ & $2.27 \%$ & $-3.46 \%$ & $-2.70 \%$ & $-20.44 \%$ & $-18.98 \%$ \\
\hline
\end{tabular}

Source: Authors' calculation based on EDAM 1996

Holding all else constant, the higher the pass-through elasticity, the higher the amount of social transfers needed to compensate the poor, and the lower the anticipated share of net fiscal savings. Figure 11 shows the trade-off between net of transfers, fiscal savings as a share of GDP and the degree of nominal devaluation with $0 \%$ and $30 \%$ (dashed lines) wage indexation. Introducing wage indexation slightly raises the expected net fiscal savings due to higher income tax revenues. At lower pass through, a higher devaluation rate initially increases net fiscal savings though it eventually falls as the devaluation rate rises. As the degree of pass-through overpass $70 \%$, fiscal savings falls at an increasing rate with rising magnitudes of devaluation. The concave pattern describing the relationship between fiscal savings net of transfer and the devaluation rate for a given pass-through elasticity is due to the increasing rate of real income loss to the poor population with higher devaluation rates.

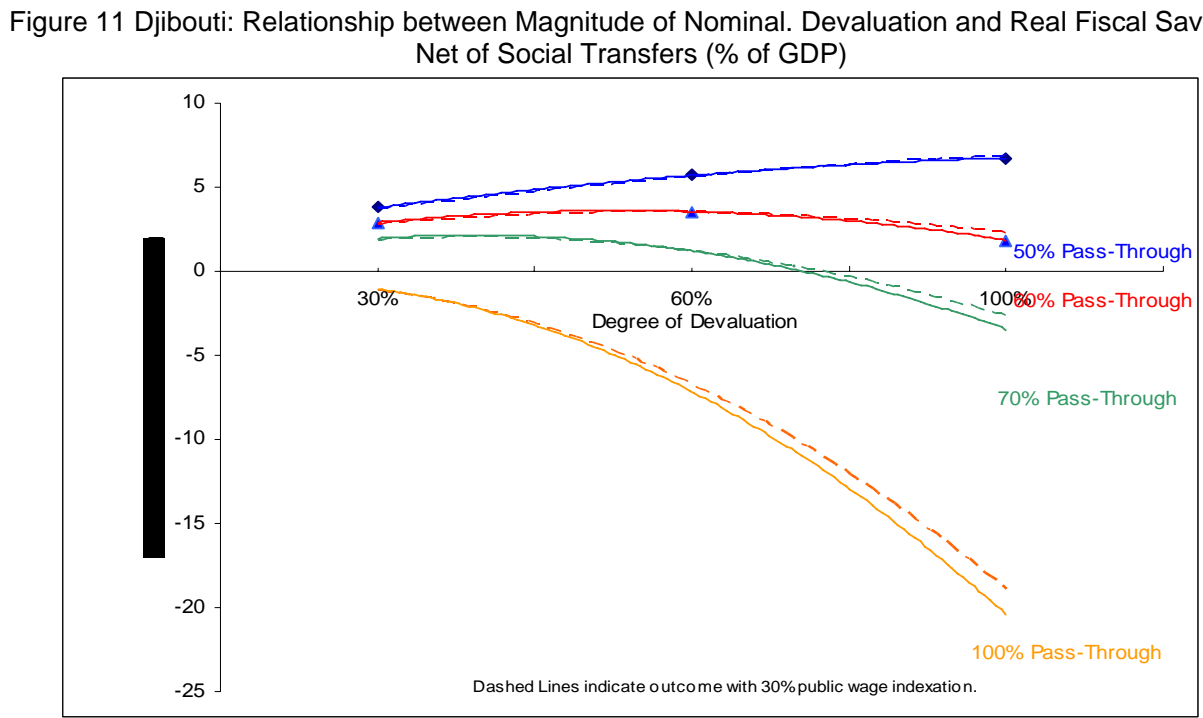

Source: Authors' calculation based on WEO, 2004 


\subsection{Estimating net fiscal savings of a nominal exchange rate devaluation assuming wage indexation}

It is possible to just offset the decline in purchasing power of civil servants through wage indexation while still generating net fiscal savings. Table A.9 in the appendix provides the level of indexation needed to maintain real public sector wages constant under a 30 percent and 60 percent nominal devaluation scenario. As expected the higher the pass-through for a given exchange rate devaluation, the greater the degree of indexation required. For example, under a 30 percent nominal devaluation scenario with a 60 percent pass-through, a wage indexation of approximately 13.4 percent will keep real public sector wages constant while still generating a net fiscal savings of 2.86 percent. Higher levels of exchange rate pass-through will reduce the net fiscal savings while raising the degree of indexation required to maintain real wages constant.

\section{Conclusions}

The rationale for a currency devaluation does not lie on the potential economic gains. Given the structure of Djibouti's economy, a nominal exchange rate devaluation is likely to be contractionary in the short-term. Unlike many other Sub-Saharan countries, Djibouti has a limited domestic productive capacity and a negligible tradable sector. The economic impact of a currency devaluation may be limited in the short-term owing to the lack of a supply response of the tradable sector. At the same time, the negative impact on aggregate demand could be sizeable. Aggregate private consumption will likely fall, due to the real income loss caused by the devaluation. Given the high dependency of the economy on imports of intermediate and capital goods, the higher relative prices of these goods will tend to reduce private investment demand in the non-tradable sector.

Given Djibouti's fiscal structure, a currency devaluation could engender substantial fiscal savings which could be reallocated to the attainment of the MDGs and to poverty reduction. A currency devaluation will boost the real value of revenues since the exchange rate typically depreciates more than the price level in the short term. The paper estimates that the first order effect of 30 percent nominal exchange rate devaluation could generate fiscal savings ranging from 3 to 7 percent of GDP (depending on the degree of exchange rate pass-through).

However, the short-term social costs of a currency devaluation may prove high. Assuming a 30 percent nominal devaluation, the incidence of poverty could rise by 5-6 percentage points. About 17 percent of households in the lowest consumption quartile could fall below the extreme poverty line and 20 percent of middle-income households (in the $3^{\text {rd }}$ quartile) could drop below the national poverty line.

Assuming that the government decides to provide social transfers to compensate the poor for their real income loss caused by the devaluation, such policy measure could still generate net fiscal savings. A 30 percent nominal devaluation could generate between 1 and 3 percent of GDP of fiscal savings net of social transfers needed to compensate the poor for their real income loss. The size of the net fiscal savings will depend on the magnitude of the devaluation, the exchange rate pass-through, and the effective enforcement of wage policy controls.

Djibouti's lack of experience with formal social safety nets limits the government's readiness to provide well-targeted and timely social transfers to compensate the poor for their real income loss caused by a currency devaluation. Setting up an effective system of social safety nets 
should be a short-term priority. It will help the government address the needs of the poor in good economic times and be adaptable to combat the adverse effect of eventual shocks.

A number of issues that were not discussed in the paper merit further analysis. A nominal exchange rate devaluation raises issues of the appropriate size and policy sequencing. First, there is the issue of the size of the exchange rate adjustment. Djibouti might need to implement a large enough adjustment in the exchange rate that would be perceived as sufficient to restore external competitiveness and achieve substantial fiscal consolidation. At the same time, the larger the size of the devaluation the larger the adverse social impact and the smaller the fiscal savings that could be generated. Second, a nominal devaluation if it is not accompanied by sustained efforts to maintain macroeconomic fundamentals will not be sufficient to achieve the desired impact on the equilibrium real exchange rate and the expected impact on fiscal consolidation.

The paper did not address the discussion of exit strategies from the currency board arrangement after the exchange rate adjustment. The currency board has provided financial stability, although it has not prevented the emergence of substantial fiscal and current account deficits. One possibility is to move to a flexible exchange rate. Djibouti's main trading partners (Ethiopia and Yemen) have already moved to a floating exchange rate regime. But moving to a flexible exchange rate regime involves significant administrative and political economy challenges to Djibouti policy makers. The Central Bank currently lacks the technical capacity to adopt and enforce the institutional requirements to establish a new nominal anchor (such as broad money targeting). In addition, Djibouti has a strong executive with limited checks and balances, and it remains unclear whether the Central Bank's independence could be preserved so as to adopt a monetary policy that would signal strong commitment to price stability. An alternative exit to the currency board could be pegging the Djibouti franc to a basket of currencies of its main trading partners, with the exchange rate fluctuating within a narrow margin that can be gradually widened in parallel with the strengthening of the Central Bank’s institutional capacity.

In the absence of a more flexible exchange rate management, the only option available to the government to resolve the problem of high factor costs and create additional fiscal space is to speed up public sector and structural reforms. As discussed in the Djibouti Country Economic Memorandum (2006) these policies could aim at: a) reforming the government pay and employment policies; b) removing bottlenecks to private sector investment; c) investing in highly-skilled vocational training; and d) reducing the price and improving the quality of backbone services (telecommunications, water, electricity, transports, finance). 


\section{References}

Campa, G. and Goldberg, L. (2002), “Exchange Rate Pass-Through into Import Prices: A Macro or Micro Phenomenon?”, NBER Working Paper 8934.

Dabusinskas, A. (2003), “Exchange Rate Pass-Through to Estonian Prices”, Estonia Central Bank.

Deaton, A. (1997), “The Analysis of Household Surveys”, World Bank Publications.

Edwards, S. (1989), “Are Devaluations Contractionary?”, Review of Economics and Statistics, vol. 68 (October 1986), pp. 501-08.

Haughton, J. and Van Kinh, H. (2003), “Does Devaluation Worsen Income Distribution? Evidence from Vietnam”, mimeo.

International Monetary Fund, 2005, “The distributional impact of devaluation in Djibouti”, mimeo.

Minot, N. (1998), "Distributional and Nutritional Impact of Devaluation in Rwanda”, Economic Development and Cultural Change, vol. 46(2) pp. 379-402.

Yiheyis, Z. (2000), "Fiscal Adjustment to Currency Devaluation in Selected African Countries: An Empirical Analysis”, African Development Review, vol. 12(1), pp. 1-23.

World Bank, (1997), “Djibouti 1997 Poverty Assessment”, World Bank, Washington, D.C. 


\section{ANNEX 1. MAIN TRANSMISSION CHANNELS THROUGH WHICH A CURRENCY DEVALUATION COULD AFFECT DJIBOUTI'S ECONOMY}

In view of the data limitations to estimate the first and second-order macroeconomic effects of a currency devaluation in Djibouti ${ }^{35}$, this appendix aims to provide a brief qualitative account of the main transmission channels through which a nominal exchange rate devaluation could affect Djibouti's economy.

External Balance. A decline in domestic real income after the devaluation is expected to reduce imports in U.S. dollar terms, which should improve the current account balance. However with half of the broad money held in foreign currency deposits, the private sector would probably draw down these deposits to offset the fall in real income, thereby dampening the impact of devaluation on import demand. Expatriate and foreign troop demand will not likely be affected by the devaluation as they are paid in foreign currency.

Real Sector. It is unlikely that devaluation would generate any supply response in the short-term owing to Djibouti's current limited local productive capacity. A reduction in real wage prices by itself might not attract foreign investors, because other factors are negatively affecting profit prospects (i.e. low appropriability of investments owing to weak protection of property rights). Moreover, if the authorities resort to public wage indexation to compensate for the decline in real earnings of civil servants the initial impact of the devaluation on unit labor costs could be partially offset by any discretionary increase in nominal public wages. Even if the real wages are lowered significantly after a devaluation, the limited supply response may lead to a negative impact on private investment and labor demand which could further exacerbate formal unemployment.

Banking Sector. The Central Bank would see an increase in the excess coverage of the currency board and commercial banks would continue to have a positive foreign currency position (assets exceed foreign exchange liabilities). However, given Djibouti's high levels of financial openness and the high share of total deposits denominated in foreign currency, an anticipated depreciation may lead to capital flight, forcing lending interest rates to rise temporarily. Higher interest rates could also have a negative impact on private investment demand.

\footnotetext{
35 The decision to devalue depends fundamentally on the degree of misalignment; on whether there will be medium to long-term economic gains and the speed to which internal adjustment mechanisms are likely to restore macroeconomic balances to ensure that the real exchange rate returns to its long-run equilibrium rate. However, measuring the degree of misalignment is difficult because it requires estimating the long - run equilibrium real exchange rate, which remains one of the most challenging empirical problems in open economy macroeconomics (Edwards 1989, Williamson 1994, Hinkle et al, 1995). A fundamental difficulty is that the equilibrium value of the real exchange rate is not observable. Standard macroeconomic theory tells us, however, that the equilibrium real exchange rate is a function of observable macroeconomic 'fundamentals'(such as government spending variables and the terms of trade), and that the actual real exchange rate approaches the equilibrium rate over time (Devarajan et al, 1993, Montiel, 1997). A recent strand of the empirical literature exploits these observations to develop a single-equation approach to estimating the equilibrium real exchange rate and the degree of misalignment (Baffes et al, 1997). But this econometric approach is data-intensive and inherits all the limitations of developing country data. The econometric results are often not robust. The overall statistical significance is highly sensitive to the choice of proxies for the macroeconomic fundamentals and to the real exchange rate estimation procedure. In countries like Djibouti, time series data limitations prove acute particularly when the notion of long-run equilibrium is required to carry so much weight in short samples.
} 
Fiscal Accounts. The fiscal effect of devaluation can be divided between a revenue and expenditure effect (see Section 4 of the paper for a more detailed account of the link between the real exchange rate and the fiscal accounts):

- Revenue Effects. The main sources of government revenue in Djibouti are taxes, grants and military aid. In static terms, a real devaluation would increase real revenues by raising real trade taxes (primarily on imports) by raising their value in terms of local currency and also generate a gain on foreign currency denominated grants and military aid. The tax base may shrink if import demand falls and furthermore if import demand is price elastic, revenues from this sector will decline.

- Expenditure Effects. Government expenditure can be decomposed into expenditure on trade and non-traded goods and services and interest payments on domestic and external debt. The immediate or static impact of devaluation is to raise government expenditure on traded goods and the local currency cost of foreign debt servicing which is marginal in Djibouti. Government spending will also be affected if devaluation causes a change in discretionary fiscal policy such as raising salaries of public sector employees to protect their real earnings from a devaluation-induced rise in prices of consumption goods. 


\section{ANNEX II. TECHNICAL APPENDIX}

Table A.1 Djibouti: Exchange Rate Pass Through for Food Index (Q2:99-Q1:04)

\begin{tabular}{|c|c|c|c|}
\hline Variables & Coefficie & & Std. Error \\
\hline constant & 0.018 & 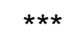 & $(0.00)$ \\
\hline $\log \_f o o d_{t-4}$ & 0.315 & $\star \star$ & (0.10) \\
\hline $\log \_n e e r$ t-6 & 0.143 & $\star \star$ & $(0.06)$ \\
\hline $\log \_n e e r_{t-7}$ & 0.264 & $\star \star \star *$ & $(0.05)$ \\
\hline log_efppi t-1 & 0.885 & & $(0.80)$ \\
\hline dummy_Q2y02 & -0.015 & $\star \star$ & $(0.00)$ \\
\hline$F(5,6)$ & & 132 & \\
\hline
\end{tabular}

Notes:

1. Standard errors are corrected for serial correlation and heterogeneity using Newey-West method with 10 lags.

2. $* * *$ denotes significance at the $1 \%$ level and $* *$ at the $5 \%$ level.

3. Dummy variable is for turning point when the nominal effective exchange rate begins to depreciate in the $2^{\text {nd }}$ quarter (Q) of 2002.

Source: CPI data and Djibouti authorities 


\section{Derivation of Growth Rates for Government Revenue and Expenditure}

Revenue

Begin with the expression,

$$
R=\left(t_{n} P_{n} Y_{n}+t_{m} E M^{*}+E F^{*}\right) / P \text {, where } P=P_{N}^{\delta}\left(E^{\tau} P^{*}\right)^{1-\delta} \text { and } P_{n}=\left(E^{\tau}\right)^{\beta} \text {. }
$$

To obtain the growth rate of revenue, fully differentiate across the expression:

$$
P d R+R d P=t_{n} P_{n} Y_{n} \frac{d Y_{N}}{Y_{N}}+t_{n} P_{n} Y_{n} \frac{d P_{N}}{P_{N}}+t_{m} E M^{*} \frac{d M^{*}}{M^{*}}+t_{m} E M \frac{d E}{E}+F^{*} E \frac{d E}{E} .
$$

Let the growth rate be denoted by $\tilde{X}=d X / X$ and assume that $\tilde{M}=0, \tilde{F}^{*}=0$ and the price index, $P=1$. Also using the fact that $\widetilde{P}=\widetilde{P}_{n}+(1-\delta) \tau \widetilde{E}$ and that $\eta_{m}, \eta_{f}$ and $\eta_{n}$ are the revenue shares of imported goods, grants and non-tradable goods and services respectively, (2) can be rewritten as

$$
\widetilde{R}=\left(\eta_{n}-\delta\right) \tilde{P}_{n}+\left(\eta_{m}+\eta_{f}-(1-\delta) \tau\right) \widetilde{E}+\left(\eta_{n} \tilde{Y}_{n}+\eta_{m} \tilde{M}^{*}\right)
$$

Using the identity $\eta_{m}+\eta_{f}+\eta_{n}=1$ and that $\widetilde{P}_{n}=\tau \beta \widetilde{E}$, after some algebraic manipulation, the expression simplifies to,

$$
\widetilde{R}=\left\{(1-\tau+\delta \tau)\left(\eta_{f}+\eta_{m}\right)+(\beta-(1-\delta) \tau) \eta_{n}-\beta \tau \delta\right\} \tilde{E}+\left(\eta_{n} \tilde{Y}_{n}+\eta_{m} \tilde{M}^{*}\right) .
$$

\section{Expenditure}

Starting with the expression,

$$
G=\left(P_{n} G_{n}+E^{\tau} G_{m}^{*}+i^{*} E \cdot E X D_{-1}\right) / P \text {, where } P=P_{N}^{\delta}\left(E^{\tau} P^{*}\right)^{1-\delta} \text { and } P_{n}=\left(E^{\tau}\right)^{\beta} \text {. }
$$

Differentiating across gives,

$$
P d G+G d P=P_{n} G_{n} \frac{d G_{n}}{G_{n}}+P_{n} G_{n} \frac{d P_{n}}{P_{n}}+\tau E^{\tau} G_{m} \frac{d E}{E}+E^{\tau} G_{m} \frac{d G_{m}}{G_{m}}+i^{*} E \cdot E X D_{-1} \frac{d E}{E} .
$$

Dividing through by $G$ and that $\varphi_{m}, \varphi_{n}$ and $\varphi_{\text {exd }}$ denotes respectively, the expenditure shares on tradable goods, non-tradable goods and interest payments on external debt, gives

$$
\widetilde{G}=\varphi_{n} \widetilde{P}_{n}+\left(\tau \varphi_{m}+\varphi_{\text {exd }}\right) \tilde{E}+\left(\varphi_{n} \widetilde{G}_{b}+\varphi_{m} \widetilde{G}_{m}\right)-\tilde{P}
$$

Using the identity $\varphi_{n}+\varphi_{n}+\varphi_{f}=1, \widetilde{P}=\widetilde{P}_{n}+(1-\delta) \tau \tilde{E}$ and that $\widetilde{P}_{n}=\tau \beta \tilde{E}$, after some algebraic manipulation, the expression simplifies to,

$$
\tilde{G}=\left\{\delta \tau \varphi_{m}+(1-\tau+\tau \delta) \varphi_{\text {exd }}+(\beta-1+\delta) \tau \varphi_{n}-\beta \tau \delta\right\} \tilde{E}+\left(\varphi_{n} \tilde{G}_{n}+\varphi_{m} \tau \widetilde{G}_{m}\right) .
$$


Table A.2a Djibouti: Poverty Impact of a Potential 30\% Nominal Devaluation (Headcount Ratio)

\begin{tabular}{|c|c|c|c|c|c|c|c|c|}
\hline \multirow[b]{3}{*}{ Households } & \multirow{2}{*}{\multicolumn{2}{|c|}{$\begin{array}{c}\text { Pre-Devaluation } \\
\text { Poverty (\% of } \\
\text { population) }\end{array}$}} & \multicolumn{6}{|c|}{ Post-Devaluation Poverty (\% of population) } \\
\hline & & & \multicolumn{2}{|c|}{$\begin{array}{c}\text { 1st Scenario } \\
\text { (50\% pass } \\
\text { through) }\end{array}$} & \multicolumn{2}{|c|}{$\begin{array}{c}\text { 2nd Scenario (60\% } \\
\text { pass through) }\end{array}$} & \multicolumn{2}{|c|}{$\begin{array}{c}\text { 3rd Scenario (70\% } \\
\text { pass through) }\end{array}$} \\
\hline & Extreme & National & Extreme & National & Extreme & National & Extreme & National \\
\hline All Djibouti & 13.4 & 48.7 & 17.2 & 53.9 & 17.8 & 55.0 & 18.9 & 56.5 \\
\hline \multicolumn{9}{|l|}{ Location } \\
\hline Urban & 8.2 & 42.1 & 11.1 & 47.6 & 11.7 & 48.8 & 12.6 & 50.4 \\
\hline Rural & 39.5 & 82.1 & 47.4 & 85.6 & 48.1 & 86.4 & 50.6 & 86.9 \\
\hline \multicolumn{9}{|l|}{ Household Head } \\
\hline Male & 11.9 & 46.3 & 15.7 & 51.3 & 16.3 & 52.6 & 17.5 & 54.1 \\
\hline Female & 18.6 & 57.1 & 22.3 & 63.1 & 22.8 & 63.5 & 23.7 & 64.6 \\
\hline \multicolumn{9}{|c|}{ Overall Income group } \\
\hline Poorest & 53.6 & 100.0 & 68.8 & 100.0 & 71.1 & 100.0 & 75.6 & 100.0 \\
\hline 2nd quartile & 0.0 & 95.0 & 0.0 & 100.0 & 0.0 & 100.0 & 0.0 & 100.0 \\
\hline 3rd quartile & 0.0 & 0.0 & 0.0 & 15.8 & 0.0 & 20.2 & 0.0 & 25.9 \\
\hline Richest & 0.0 & 0.0 & 0.0 & 0.0 & 0.0 & 0.0 & 0.0 & 0.0 \\
\hline \multicolumn{9}{|c|}{ Male Head: Income group } \\
\hline Poorest & 50.7 & 100.0 & 66.9 & 100.0 & 69.4 & 100.0 & 74.5 & 100.0 \\
\hline 2nd quartile & 0.0 & 95.5 & 0.0 & 100.0 & 0.0 & 100.0 & 0.0 & 100.0 \\
\hline 3rd quartile & 0.0 & 0.0 & 0.0 & 15.5 & 0.0 & 20.7 & 0.0 & 26.7 \\
\hline Richest & 0.0 & 0.0 & 0.0 & 0.0 & 0.0 & 0.0 & 0.0 & 0.0 \\
\hline \multicolumn{9}{|c|}{ Female Head: Income group } \\
\hline Poorest & 61.3 & 100.0 & 73.6 & 100.0 & 75.5 & 100.0 & 78.5 & 100.0 \\
\hline 2nd quartile & 0.0 & 93.5 & 0.0 & 100.0 & 0.0 & 100.0 & 0.0 & 100.0 \\
\hline 3rd quartile & 0.0 & 0.0 & 0.0 & 16.8 & 0.0 & 18.3 & 0.0 & 22.9 \\
\hline Richest & 0.0 & 0.0 & 0.0 & 0.0 & 0.0 & 0.0 & 0.0 & 0.0 \\
\hline Gini Coefficient $^{a}$ & \multicolumn{2}{|c|}{40.8} & \multicolumn{2}{|c|}{41.5} & \multicolumn{2}{|c|}{41.7} & \multicolumn{2}{|c|}{41.9} \\
\hline
\end{tabular}

\section{Notes:}

1. Extreme poverty line is Fdj 100,229 (USD 1.55/day) while the National Poverty Line is Fdj 216,450 (USD 3.35/day) in 1996.

2. 1st, 2nd and 3rd scenarios correspond to using a long-run elasticity of traded good prices to the nominal exchange rate of $0.5,0.6$ and 0.7 respectively.

a/ Households were ranked by adult equivalent expenditure.

Source: Authors' calculation based on EDAM 1996 
Table A.2b Djibouti: Poverty Impact of a Potential 30\% Nominal Devaluation (Headcount Ratio)

\begin{tabular}{|c|c|c|c|c|c|c|c|c|}
\hline \multirow[b]{3}{*}{ Households } & & & \multicolumn{6}{|c|}{ Post-Devaluation Poverty (\% of population) } \\
\hline & \multicolumn{2}{|c|}{$\begin{array}{c}\text { Pre-Devaluation } \\
\text { Poverty Count (\%) }\end{array}$} & \multicolumn{2}{|c|}{$\begin{array}{l}\text { 1st Scenario }(50 \% \\
\text { pass through) }\end{array}$} & \multicolumn{2}{|c|}{$\begin{array}{c}\text { 2nd Scenario } \\
\text { (60\% pass through) }\end{array}$} & \multicolumn{2}{|c|}{$\begin{array}{c}\text { 3rd Scenario }(70 \% \\
\text { pass through) }\end{array}$} \\
\hline & Extreme & National & Extreme & National & Extreme & National & Extreme & National \\
\hline All Djibouti & 13.4 & 48.7 & 17.2 & 53.9 & 17.8 & 55.0 & 18.9 & 56.5 \\
\hline \multicolumn{9}{|l|}{ By Main Wage Source: } \\
\hline Public Administration & 8.7 & 39.8 & 11.5 & 45.0 & 11.9 & 45.9 & 13.1 & 48.0 \\
\hline Services & 7.6 & 44.1 & 14.7 & 47.6 & 15.3 & 48.8 & 15.9 & 51.8 \\
\hline Commerce & 12.9 & 49.8 & 16.6 & 54.4 & 17.5 & 56.2 & 18.0 & 58.5 \\
\hline Transport and Telecommunication & 6.9 & 30.4 & 9.8 & 33.3 & 9.8 & 34.3 & 10.8 & 35.3 \\
\hline \multicolumn{9}{|l|}{ Main Wage Source: Public Administration } \\
\hline Poorest & 51.1 & 100.0 & 67.4 & 100.0 & 69.6 & 100.0 & 77.2 & 100.0 \\
\hline 2nd quartile & 0.0 & 96.1 & 0.0 & 100.0 & 0.0 & 100.0 & 0.0 & 100.0 \\
\hline 3rd quartile & 0.0 & 0.0 & 0.0 & 15.1 & 0.0 & 18.4 & 0.0 & 25.7 \\
\hline Richest & 0.0 & 0.0 & 0.0 & 0.0 & 0.0 & 0.0 & 0.0 & 0.0 \\
\hline \multicolumn{9}{|l|}{ Main Wage Source: Services } \\
\hline Poorest & 33.3 & 100.0 & 64.1 & 100.0 & 66.7 & 100.0 & 69.2 & 100.0 \\
\hline 2nd quartile & 0.0 & 97.3 & 0.0 & 100.0 & 0.0 & 100.0 & 0.0 & 100.0 \\
\hline 3rd quartile & 0.0 & 0.0 & 0.0 & 10.6 & 0.0 & 14.9 & 0.0 & 25.5 \\
\hline Richest & 0.0 & 0.0 & 0.0 & 0.0 & 0.0 & 0.0 & 0.0 & 0.0 \\
\hline \multicolumn{9}{|l|}{ Main Wage Source: Commerce } \\
\hline Poorest & 52.8 & 100.0 & 67.9 & 100.0 & 71.7 & 100.0 & 73.6 & 100.0 \\
\hline 2nd quartile & 0.0 & 94.8 & 0.0 & 100.0 & 0.0 & 100.0 & 0.0 & 100.0 \\
\hline 3rd quartile & 0.0 & 0.0 & 0.0 & 13.0 & 0.0 & 20.4 & 0.0 & 29.6 \\
\hline Richest & 0.0 & 0.0 & 0.0 & 0.0 & 0.0 & 0.0 & 0.0 & 0.0 \\
\hline \multicolumn{9}{|l|}{ Main Wage Source: Transport \& Telecom } \\
\hline Poorest & 50.0 & 100.0 & 71.4 & 100.0 & 71.4 & 100.0 & 78.6 & 100.0 \\
\hline 2nd quartile & 0.0 & 100.0 & 0.0 & 100.0 & 0.0 & 100.0 & 0.0 & 100.0 \\
\hline 3rd quartile & 0.0 & 0.0 & 0.0 & 12.5 & 0.0 & 16.7 & 0.0 & 20.8 \\
\hline Richest & 0.0 & 0.0 & 0.0 & 0.0 & 0.0 & 0.0 & 0.0 & 0.0 \\
\hline \multicolumn{9}{|c|}{ Notes: } \\
\hline \multicolumn{9}{|c|}{$\begin{array}{l}\text { 1. Extreme poverty line is Fdj } 100,229 \text { (USD 1.55/day) while the National Poverty Line is Fdj } 216,450 \text { (USD } 3.35 / \text { day) in } 1996 \text {. } \\
\text { 2. 1st, } 2 \text { nd and 3rd scenarios correspond to using a long-run elasticity of traded good prices to the nominal exchange rate of } 0.5,0.6 \text { and } 0.7 \\
\text { respectively. }\end{array}$} \\
\hline \multicolumn{9}{|c|}{$\begin{array}{l}\text { 3. There were } 603 \text { households where wage earnings from public administration formed over } 90 \text { percent of the total wage income earned by the } \\
\text { household. Similarly, } 183 \text { households had earnings from services were over } 90 \% \text { of the total, } 245 \text { from commerce and } 114 \text { from transport and } \\
\text { telecommunication. }\end{array}$} \\
\hline
\end{tabular}


Table A.2c Djibouti: Poverty Impact of a Potential 30\% Nominal Devaluation (Poverty Gap)

\begin{tabular}{|c|c|c|c|c|c|c|c|c|}
\hline \multirow[b]{3}{*}{ Households } & & & \multicolumn{6}{|c|}{ Post-Devaluation Poverty Gap (\%) } \\
\hline & \multicolumn{2}{|c|}{$\begin{array}{l}\text { Pre-Devaluation } \\
\text { Poverty Gap (\%) }\end{array}$} & \multicolumn{2}{|c|}{$\begin{array}{c}\text { 1st Scenario } \\
\text { (50\% pass through) }\end{array}$} & \multicolumn{2}{|c|}{$\begin{array}{c}\text { 2nd Scenario } \\
\text { (60\% pass through) }\end{array}$} & \multicolumn{2}{|c|}{$\begin{array}{c}\text { 3rd Scenario } \\
\text { (70\% pass through) }\end{array}$} \\
\hline & Extreme & National & Extreme & National & Extreme & National & Extreme & National \\
\hline All Djibouti & 31.3 & 38.8 & 31.9 & 41.3 & 32.6 & 41.8 & 32.4 & 42.2 \\
\hline \multicolumn{9}{|l|}{ Location } \\
\hline Urban & 27.7 & 34.2 & 27.4 & 36.7 & 27.9 & 37.2 & 27.7 & 37.5 \\
\hline Rural & 35.1 & 50.4 & 37.2 & 54.1 & 38.4 & 54.9 & 38.3 & 55.6 \\
\hline \multicolumn{9}{|l|}{ Household Head } \\
\hline Male $\quad(77.4 \%)$ & 30.7 & 38.0 & 30.8 & 40.7 & 31.4 & 41.0 & 31.1 & 41.3 \\
\hline Female (22.6\%) & 32.8 & 40.9 & 34.8 & 43.1 & 35.7 & 44.1 & 36.0 & 44.7 \\
\hline \multicolumn{9}{|l|}{ Overall Income group } \\
\hline Poorest & 31.3 & 57.3 & 31.9 & 62.1 & 32.6 & 63.1 & 32.4 & 64.1 \\
\hline 2nd quartile & - & 19.2 & - & 26.5 & - & 28.1 & - & 29.8 \\
\hline 3rd quartile & - & - & - & 3.4 & - & 4.7 & - & 5.7 \\
\hline Richest & - & - & - & - & - & - & - & - \\
\hline \multicolumn{9}{|c|}{ Male Head: Income group } \\
\hline Poorest & 30.7 & 56.5 & 30.8 & 61.4 & 31.4 & 62.4 & 31.1 & 63.4 \\
\hline 2nd quartile & - & 19.0 & - & 26.4 & - & 28.1 & - & 29.8 \\
\hline 3rd quartile & - & - & - & 3.2 & - & 4.4 & - & 5.4 \\
\hline Richest & - & - & - & - & - & - & - & - \\
\hline \multicolumn{9}{|c|}{ Female Head: Income group } \\
\hline Poorest & 32.8 & 59.4 & 34.8 & 64.0 & 35.7 & 65.0 & 36.0 & 65.9 \\
\hline 2nd quartile & - & 20.0 & - & 26.6 & - & 28.2 & - & 29.8 \\
\hline 3rd quartile & - & - & - & 3.8 & - & 5.8 & - & 6.7 \\
\hline Richest & - & - & - & - & - & - & - & - \\
\hline Gini Coefficient $^{\mathrm{a}}$ & 40 & 0.8 & & 1.5 & & 1.7 & & 1.9 \\
\hline
\end{tabular}

Notes:

1. Extreme per-capita poverty line is Fdj 100,229 (USD 1.55/day) while the National Poverty Line is Fdj 216,450 (USD 3.35/day) in 1996 .

2. The poverty gap is defined as (1-average per-capita income/poverty line) for households below the poverty line.

3. 1st, 2nd and 3rd scenarios correspond to using a long-run elasticity of traded good prices to the nominal exchange rate of $0.5,0.6$ and 0.7 respectively.

a/ Households were ranked by adult equivalent expenditure.

Source: Authors' calculation based on EDAM 1996 
Table A.2d Djibouti: Poverty Impact of a Potential 30\% Nominal Devaluation (Poverty Gap)

\begin{tabular}{|c|c|c|c|c|c|c|c|c|}
\hline \multirow[b]{3}{*}{ Households } & & & \multicolumn{6}{|c|}{ Post-Devaluation Poverty (\% of population) } \\
\hline & \multicolumn{2}{|c|}{$\begin{array}{l}\text { Pre-Devaluation } \\
\text { Poverty Gap }\end{array}$} & \multicolumn{2}{|c|}{$\begin{array}{l}\text { 1st Scenario } \\
(50 \% \text { pass through) }\end{array}$} & \multicolumn{2}{|c|}{$\begin{array}{l}\text { 1st Scenario } \\
(60 \% \text { pass through })\end{array}$} & \multicolumn{2}{|c|}{$\begin{array}{l}\text { 3rd Scenario }(70 \% \\
\text { pass through) }\end{array}$} \\
\hline & Extreme & National & Extreme & National & Extreme & National & Extreme & National \\
\hline All Djibouti & 31.3 & 38.8 & 31.9 & 41.3 & 32.6 & 41.8 & 32.4 & 42.2 \\
\hline \multicolumn{9}{|l|}{ By Main Wage Source: } \\
\hline Public Administration & 30.6 & 34.6 & 30.9 & 37.2 & 31.8 & 37.9 & 30.5 & 37.6 \\
\hline Services & 27.2 & 36.3 & 21.2 & 40.0 & 22.3 & 40.4 & 23.5 & 39.5 \\
\hline Commerce & 24.9 & 37.2 & 27.2 & 40.5 & 27.6 & 40.5 & 28.8 & 40.3 \\
\hline Transport and Telecommunication & 13.6 & 33.5 & 20.0 & 37.6 & 22.3 & 38.0 & 22.5 & 38.5 \\
\hline \multicolumn{9}{|l|}{ Main Wage Source: Public Administration } \\
\hline Poorest & 30.6 & 56.8 & 30.9 & 61.8 & 31.8 & 62.8 & 30.5 & 63.8 \\
\hline 2nd quartile & - & 18.0 & - & 25.7 & - & 27.4 & - & 29.1 \\
\hline 3rd quartile & - & . & - & 2.6 & - & 4.2 & - & 4.9 \\
\hline Richest & - & . & - & - & - & - & - & - \\
\hline \multicolumn{9}{|l|}{ Main Wage Source: Services } \\
\hline Poorest & 27.2 & 52.9 & 21.2 & 58.1 & 22.3 & 59.1 & 23.5 & 60.1 \\
\hline 2nd quartile & - & 18.4 & - & 26.0 & - & 27.6 & - & 29.2 \\
\hline 3rd quartile & - & - & - & 2.7 & - & 4.2 & - & 4.3 \\
\hline Richest & - & - & - & - & - & - & - & - \\
\hline \multicolumn{9}{|l|}{ Main Wage Source: Commerce } \\
\hline Poorest & 24.9 & 55.3 & 27.2 & 60.3 & 27.6 & 61.3 & 28.8 & 62.2 \\
\hline 2nd quartile & - & 19.8 & - & 26.8 & - & 28.5 & - & 30.1 \\
\hline 3rd quartile & - & - & - & 3.5 & - & 3.9 & - & 4.6 \\
\hline Richest & - & - & - & - & - & - & - & - \\
\hline \multicolumn{9}{|l|}{ Main Wage Source: Transport \& Telecom } \\
\hline Poorest & 13.6 & 52.8 & 20.0 & 58.5 & 22.3 & 59.7 & 22.5 & 60.8 \\
\hline 2nd quartile & - & 17.6 & - & 26.2 & - & 27.9 & - & 29.6 \\
\hline 3rd quartile & - & - & - & 4.0 & - & 5.2 & - & 6.2 \\
\hline Richest & - & - & - & - & - & - & - & - \\
\hline \multicolumn{9}{|c|}{$\begin{array}{l}\text { Notes: } \\
\text { 1. Extreme poverty line is Fdj 100,229 (USD 1.55/day) while the National Poverty Line is Fdj 216,450 (USD 3.35/day) in } 1996 .\end{array}$} \\
\hline \multicolumn{9}{|c|}{ 2. The poverty gap is defined as (1-average per-capita income/poverty line) for households below the poverty line. } \\
\hline \multicolumn{9}{|c|}{$\begin{array}{l}\text { 3. 1st, } 2 \text { nd and 3rd scenarios correspond to using a long-run elasticity of traded good prices to the nominal exchange rate of } 0.5,0.6 \text { and } 0.7 \\
\text { respectively. }\end{array}$} \\
\hline \multicolumn{9}{|c|}{$\begin{array}{l}\text { 4. There were } 603 \text { households where wage earnings from public administration formed over } 90 \text { percent of the total wage income earned by the } \\
\text { household. Similarly, } 183 \text { households had earnings from services were over } 90 \% \text { of the total, } 245 \text { from commerce and } 114 \text { for transport and } \\
\text { telecommunication. }\end{array}$} \\
\hline Source: Authors' calculation based on $E$ & 1996 & & & & & & & \\
\hline
\end{tabular}


Figure A.3 Djibouti: Surface plot of joint density of real income loss as a \% of initial expenditure against log per-capita expenditure in 1996 using $60 \%$ pass-through.

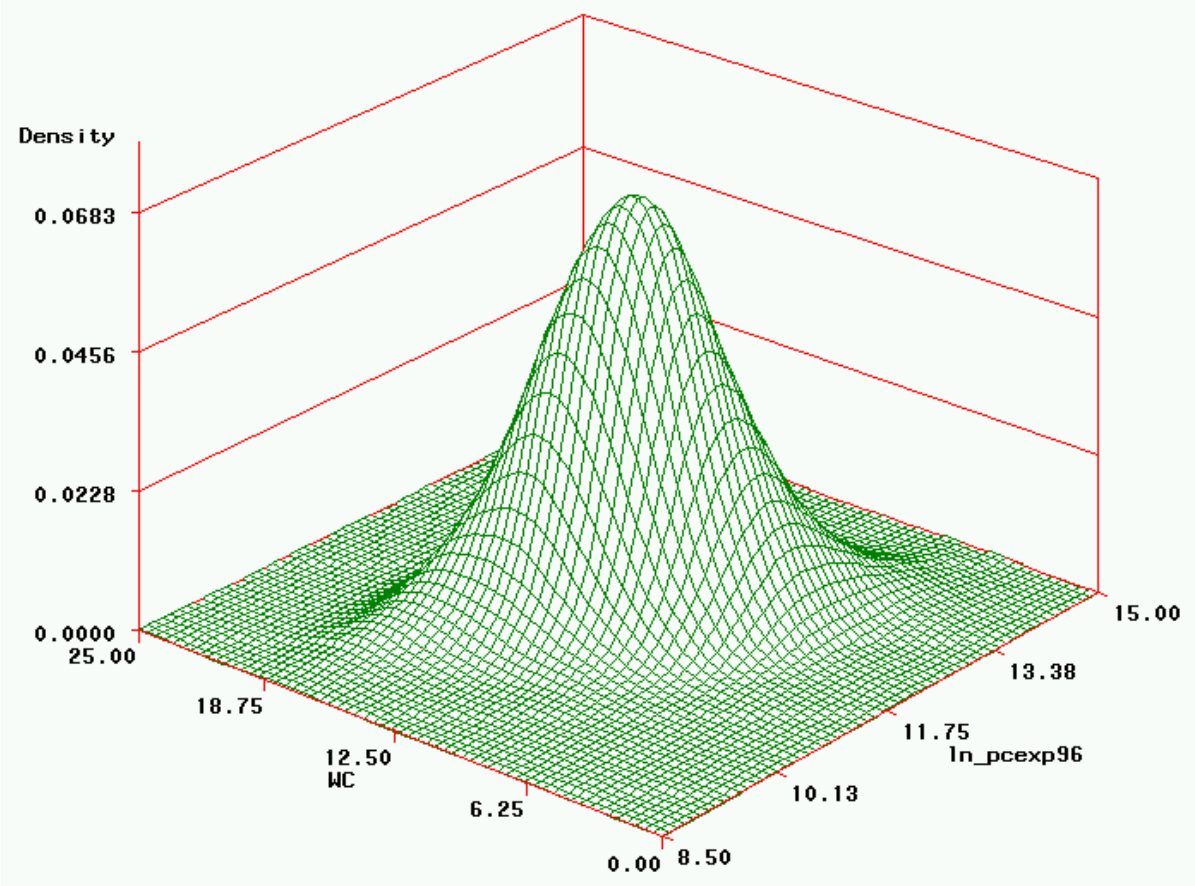

Figure A.4 Djibouti: Contour plot of joint density of real income loss as a \% of initial expenditure against log per-capita expenditure in 1996 using 60\% pass-through.

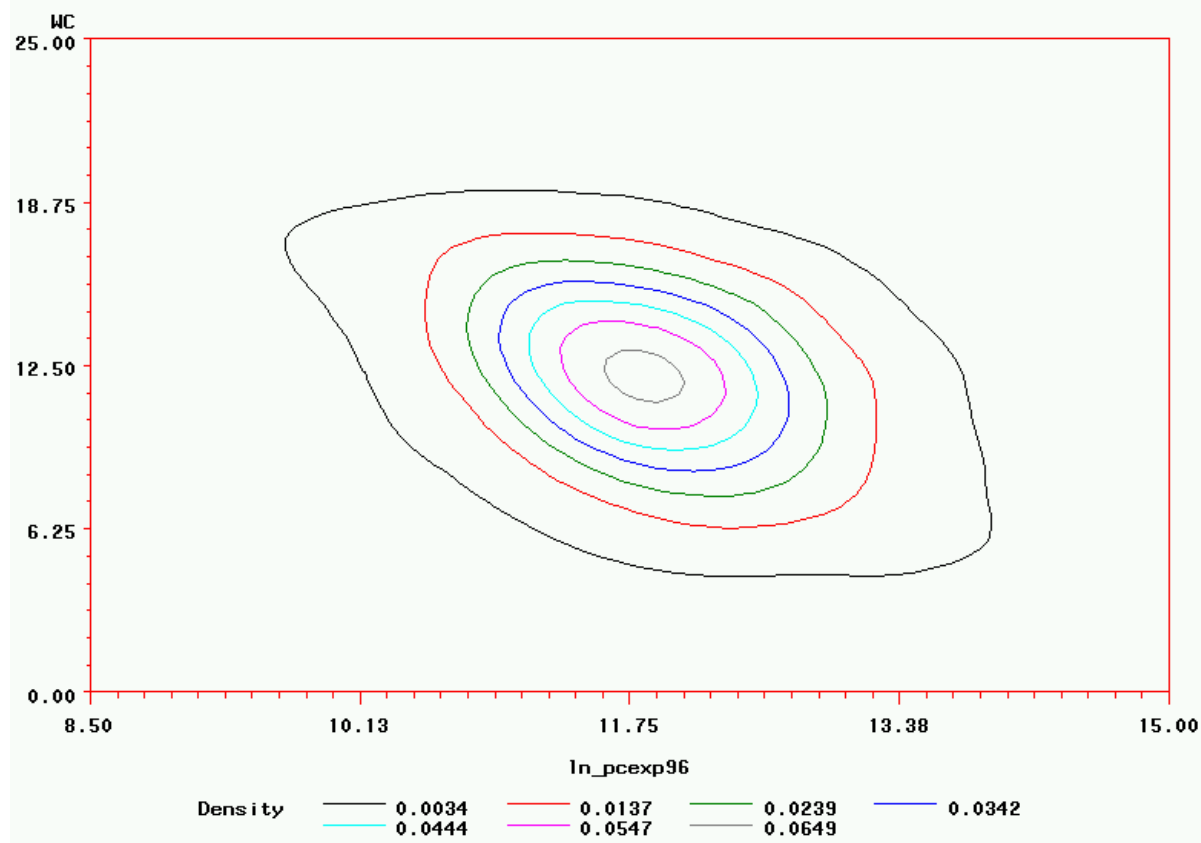


Table A.3b Djibouti: Real Income Loss to Poor Households due to of $30 \%$ Nom. Devaluation with $30 \%$ Public Wage Indexation

\begin{tabular}{|c|c|c|c|c|c|c|c|c|c|c|c|c|}
\hline & \multirow{2}{*}{$\begin{array}{c}\mathrm{HH} \\
\text { Sample } \\
\text { Size } \\
1996\end{array}$} & \multicolumn{2}{|c|}{$\begin{array}{c}\mathrm{HH} . \text { in } \\
\text { population } \\
\text { Extrapolated }\end{array}$} & \multirow[b]{2}{*}{$\begin{array}{c}\text { Sample-Pop } \\
\text { Ratio }\end{array}$} & \multicolumn{2}{|c|}{$50 \%$ pass-through } & \multicolumn{2}{|c|}{$60 \%$ pass-through } & \multicolumn{2}{|c|}{$70 \%$ pass-through } & \multicolumn{2}{|c|}{$100 \%$ pass-through } \\
\hline & & 1996 & 2005 & & $\begin{array}{l}\text { Sample } \\
\text { (DF bil) }\end{array}$ & $\begin{array}{l}\text { ropulatıon } \\
\text { (DF bil) }\end{array}$ & $\begin{array}{l}\text { sample } \\
\text { (DF bil) }\end{array}$ & $\begin{array}{l}\text { ropulatıon } \\
\text { (DF bil) }\end{array}$ & $\begin{array}{l}\text { sample } \\
\text { (DF bil) }\end{array}$ & $\begin{array}{l}\text { ropulatıon } \\
\text { (DF bil) }\end{array}$ & $\begin{array}{l}\text { Sample } \\
\text { (DF bil) }\end{array}$ & $\begin{array}{l}\text { ropulatıon } \\
\text { (DF bil) }\end{array}$ \\
\hline djibouti-ville 1 & 315 & 6195 & 8083 & 25.7 & 0.01 & 0.16 & 0.01 & 0.20 & 0.01 & 0.24 & 0.02 & 0.41 \\
\hline djibouti-ville - & 484 & 9519 & 12420 & 25.7 & 0.02 & 0.42 & 0.02 & 0.53 & 0.03 & 0.66 & 0.04 & 1.09 \\
\hline djibouti-ville - & 152 & 2989 & 3900 & 25.7 & 0.00 & 0.08 & 0.00 & 0.10 & 0.00 & 0.12 & 0.01 & 0.24 \\
\hline djibouti-ville - & 363 & 7139 & 9315 & 25.7 & 0.02 & 0.43 & 0.02 & 0.52 & 0.02 & 0.63 & 0.04 & 0.95 \\
\hline djibouti-ville - & 277 & 5507 & 7185 & 25.9 & 0.01 & 0.29 & 0.01 & 0.36 & 0.02 & 0.43 & 0.03 & 0.70 \\
\hline ali-sabieh urbai & 147 & 1728 & 2255 & 15.3 & 0.01 & 0.11 & 0.01 & 0.13 & 0.01 & 0.16 & 0.02 & 0.25 \\
\hline dikhil urbain & 124 & 1457 & 1901 & 15.3 & 0.01 & 0.08 & 0.01 & 0.10 & 0.01 & 0.12 & 0.01 & 0.18 \\
\hline arta, wea & 44 & 517 & 675 & 15.3 & 0.00 & 0.03 & 0.00 & 0.04 & 0.00 & 0.05 & 0.01 & 0.08 \\
\hline obock urbain & 25 & 293 & 382 & 15.3 & 0.00 & 0.01 & 0.00 & 0.02 & 0.00 & 0.02 & 0.00 & 0.03 \\
\hline tadjourah urbain & 52 & 624 & 814 & 15.7 & 0.00 & 0.03 & 0.00 & 0.04 & 0.00 & 0.05 & 0.00 & 0.07 \\
\hline ali-sabieh rural & 125 & 813 & 1061 & 8.5 & 0.01 & 0.05 & 0.01 & 0.06 & 0.01 & 0.07 & 0.01 & 0.12 \\
\hline dikhil rural & 77 & 500 & 652 & 8.5 & 0.00 & 0.03 & 0.00 & 0.04 & 0.01 & 0.04 & 0.01 & 0.06 \\
\hline djibouti rural & 114 & 741 & 967 & 8.5 & 0.00 & 0.04 & 0.01 & 0.05 & 0.01 & 0.06 & 0.01 & 0.08 \\
\hline tadjourah rural & 81 & 545 & 711 & 8.8 & 0.00 & 0.03 & 0.00 & 0.03 & 0.00 & 0.04 & 0.01 & 0.06 \\
\hline Total & 2380 & 38567 & 50321 & 21.1 & 0.09 & 1.78 & 0.11 & 2.22 & 0.13 & 2.69 & 0.21 & 4.33 \\
\hline$\%$ of 2005 GDP & - & - & - & - & 0.07 & 1.46 & 0.09 & 1.81 & 0.11 & 2.20 & 0.17 & 3.54 \\
\hline
\end{tabular}

Note: Cost is expressed in billions of 2004 DF. Number of sedentary households (HH) in 1996 are taken from the EDAM 1996 sample design while the numbers in 2005 are obtained by assuming an annual growth rate of $3 \%$ since 1996.

Table A.4a Djibouti: Real Income Loss to Poor Households due to of $60 \%$ Nom. Devaluation with $0 \%$ Public Wage Indexation

\begin{tabular}{|c|c|c|c|c|c|c|c|c|c|c|c|c|}
\hline & \multirow{2}{*}{$\begin{array}{c}\mathrm{HH} \\
\text { Sample } \\
\text { Size } \\
1996\end{array}$} & \multicolumn{2}{|c|}{$\begin{array}{c}\mathrm{HH} \text {. in } \\
\text { population } \\
\text { Extrapolated }\end{array}$} & \multirow[b]{2}{*}{$\begin{array}{l}\text { Sample- } \\
\text { Pop Ratio }\end{array}$} & \multicolumn{2}{|c|}{$50 \%$ pass-through } & \multicolumn{2}{|c|}{$60 \%$ pass-through } & \multicolumn{2}{|c|}{$70 \%$ pass-through } & \multicolumn{2}{|c|}{$100 \%$ pass-through } \\
\hline & & 1996 & 2005 & & $\begin{array}{l}\text { Sample } \\
\text { (DF bil) }\end{array}$ & $\begin{array}{l}\text { Population } \\
\text { (DF bil) }\end{array}$ & $\begin{array}{l}\text { Sample } \\
\text { (DF bil) }\end{array}$ & $\begin{array}{l}\text { Population } \\
\text { (DF bil) }\end{array}$ & $\begin{array}{l}\text { Sample } \\
\text { (DF bil) }\end{array}$ & $\begin{array}{l}\text { Population } \\
\text { (DF bil) }\end{array}$ & $\begin{array}{l}\text { Sample } \\
\text { (DF bil) }\end{array}$ & $\begin{array}{l}\text { Population } \\
\text { (DF bil) }\end{array}$ \\
\hline djibouti-ville 1 & 315 & 6195 & 8083 & 25.7 & 0.02 & 0.46 & 0.02 & 0.60 & 0.03 & 0.78 & 0.07 & 1.88 \\
\hline djibouti-ville - & 484 & 9519 & 12420 & 25.7 & 0.05 & 1.24 & 0.07 & 1.69 & 0.09 & 2.20 & 0.17 & 4.27 \\
\hline djibouti-ville - & 152 & 2989 & 3900 & 25.7 & 0.01 & 0.30 & 0.01 & 0.38 & 0.02 & 0.51 & 0.04 & 1.07 \\
\hline djibouti-ville - & 363 & 7139 & 9315 & 25.7 & 0.04 & 1.05 & 0.05 & 1.37 & 0.07 & 1.67 & 0.11 & 2.84 \\
\hline djibouti-ville - & 277 & 5507 & 7185 & 25.9 & 0.03 & 0.76 & 0.04 & 0.95 & 0.05 & 1.17 & 0.07 & 1.89 \\
\hline ali-sabieh urbai & 147 & 1728 & 2255 & 15.3 & 0.02 & 0.28 & 0.02 & 0.36 & 0.03 & 0.45 & 0.05 & 0.70 \\
\hline dikhil urbain & 124 & 1457 & 1901 & 15.3 & 0.01 & 0.21 & 0.02 & 0.27 & 0.02 & 0.34 & 0.04 & 0.58 \\
\hline arta, wea & 44 & 517 & 675 & 15.3 & 0.01 & 0.08 & 0.01 & 0.10 & 0.01 & 0.12 & 0.01 & 0.19 \\
\hline obock urbain & 25 & 293 & 382 & 15.3 & 0.00 & 0.03 & 0.00 & 0.04 & 0.00 & 0.05 & 0.01 & 0.10 \\
\hline tadjourah urbain & 52 & 624 & 814 & 15.7 & 0.01 & 0.08 & 0.01 & 0.10 & 0.01 & 0.12 & 0.01 & 0.19 \\
\hline ali-sabieh rural & 125 & 813 & 1061 & 8.5 & 0.02 & 0.13 & 0.02 & 0.16 & 0.02 & 0.20 & 0.03 & 0.29 \\
\hline dikhil rural & 77 & 500 & 652 & 8.5 & 0.01 & 0.07 & 0.01 & 0.08 & 0.01 & 0.10 & 0.02 & 0.14 \\
\hline djibouti rural & 114 & 741 & 967 & 8.5 & 0.01 & 0.09 & 0.01 & 0.11 & 0.02 & 0.14 & 0.03 & 0.24 \\
\hline tadjourah rural & 81 & 545 & 711 & 8.8 & 0.01 & 0.07 & 0.01 & 0.08 & 0.01 & 0.10 & 0.02 & 0.16 \\
\hline Total & 2380 & 38567 & 50321 & 21.1 & 0.24 & 4.86 & 0.30 & 6.29 & 0.38 & 7.94 & 0.68 & 14.54 \\
\hline$\%$ of 2005 GDP & - & - & - & - & 0.19 & 3.97 & 0.25 & 5.14 & 0.31 & 6.49 & 0.55 & 11.88 \\
\hline
\end{tabular}

Note: Cost is expressed in billions of 2004 DF. Number of sedentary households (HH) in 1996 are taken from the EDAM 1996 sample design while the numbers in 2005 are obtained by assuming an annual growth rate of $3 \%$ since 1996.

Table A.4b Djibouti: Real Income Loss to Poor Households due to of $60 \%$ Nom. Devaluation with $30 \%$ Public Wage Indexation

\begin{tabular}{|c|c|c|c|c|c|c|c|c|c|c|c|c|}
\hline & \multirow{2}{*}{$\begin{array}{c}\mathrm{HH} \\
\text { Sample } \\
\text { Size } \\
1996\end{array}$} & \multicolumn{2}{|c|}{$\begin{array}{c}\mathrm{HH} \text {. in } \\
\text { population } \\
\text { Extrapolated }\end{array}$} & \multirow[b]{2}{*}{$\begin{array}{c}\text { Sample-Pop } \\
\text { Ratio }\end{array}$} & \multicolumn{2}{|c|}{$50 \%$ pass-through } & \multicolumn{2}{|c|}{$60 \%$ pass-through } & \multicolumn{2}{|c|}{$70 \%$ pass-through } & \multicolumn{2}{|c|}{$100 \%$ pass-through } \\
\hline & & 1996 & 2005 & & $\begin{array}{l}\text { Sample } \\
\text { (DF bil) }\end{array}$ & $\begin{array}{c}\text { ropulatıon } \\
\text { (DF bil) }\end{array}$ & $\begin{array}{l}\text { Sample } \\
\text { (DF bil) }\end{array}$ & $\begin{array}{c}\text { ropulatıon } \\
\text { (DF bil) }\end{array}$ & $\begin{array}{l}\text { Sample } \\
\text { (DF bil) }\end{array}$ & $\begin{array}{c}\text { ropulatıon } \\
\text { (DF bil) }\end{array}$ & $\begin{array}{l}\text { Sample } \\
\text { (DF bil) }\end{array}$ & $\begin{array}{l}\text { Populatıon } \\
\text { (DF bil) }\end{array}$ \\
\hline djibouti-ville 1 & 315 & 6195 & 8083 & 25.7 & 0.02 & 0.41 & 0.02 & 0.54 & 0.03 & 0.71 & 0.06 & 1.61 \\
\hline djibouti-ville - & 484 & 9519 & 12420 & 25.7 & 0.04 & 1.09 & 0.06 & 1.47 & 0.08 & 1.94 & 0.14 & 3.70 \\
\hline djibouti-ville - & 152 & 2989 & 3900 & 25.7 & 0.01 & 0.24 & 0.01 & 0.34 & 0.02 & 0.44 & 0.04 & 0.94 \\
\hline djibouti-ville - & 363 & 7139 & 9315 & 25.7 & 0.04 & 0.95 & 0.05 & 1.23 & 0.06 & 1.52 & 0.10 & 2.51 \\
\hline djibouti-ville - & 277 & 5507 & 7185 & 25.9 & 0.03 & 0.70 & 0.03 & 0.86 & 0.04 & 1.06 & 0.07 & 1.73 \\
\hline ali-sabieh urbai & 147 & 1728 & 2255 & 15.3 & 0.02 & 0.25 & 0.02 & 0.31 & 0.02 & 0.38 & 0.04 & 0.61 \\
\hline dikhil urbain & 124 & 1457 & 1901 & 15.3 & 0.01 & 0.18 & 0.01 & 0.23 & 0.02 & 0.27 & 0.03 & 0.46 \\
\hline arta, wea & 44 & 517 & 675 & 15.3 & 0.01 & 0.08 & 0.01 & 0.09 & 0.01 & 0.12 & 0.01 & 0.18 \\
\hline obock urbain & 25 & 293 & 382 & 15.3 & 0.00 & 0.03 & 0.00 & 0.03 & 0.00 & 0.04 & 0.01 & 0.08 \\
\hline tadjourah urbain & 52 & 624 & 814 & 15.7 & 0.00 & 0.07 & 0.01 & 0.09 & 0.01 & 0.11 & 0.01 & 0.16 \\
\hline ali-sabieh rural & 125 & 813 & 1061 & 8.5 & 0.01 & 0.12 & 0.02 & 0.14 & 0.02 & 0.17 & 0.03 & 0.25 \\
\hline dikhil rural & 77 & 500 & 652 & 8.5 & 0.01 & 0.06 & 0.01 & 0.08 & 0.01 & 0.09 & 0.02 & 0.13 \\
\hline djibouti rural & 114 & 741 & 967 & 8.5 & 0.01 & 0.08 & 0.01 & 0.10 & 0.02 & 0.13 & 0.03 & 0.23 \\
\hline tadjourah rural & 81 & 545 & 711 & 8.8 & 0.01 & 0.06 & 0.01 & 0.07 & 0.01 & 0.08 & 0.01 & 0.12 \\
\hline Total & 2380 & 38567 & 50321 & 21.1 & 0.21 & 4.33 & 0.27 & 5.59 & 0.33 & 7.04 & 0.59 & 12.71 \\
\hline$\%$ of 2005 GDP & - & - & - & - & 0.17 & 3.54 & 0.22 & 4.57 & 0.27 & 5.75 & 0.48 & 10.38 \\
\hline
\end{tabular}

Note: Cost is expressed in billions of 2004 DF. Number of sedentary households (HH) in 1996 are taken from the EDAM 1996 sample design

while the numbers in 2005 are obtained by assuming an annual growth rate of 3\% since 1996 . 
Table A.5a Djibouti: Real Income Loss to Poor Households due to of $100 \%$ Nom. Devaluation with $0 \%$ Public Wage Indexation

\begin{tabular}{|c|c|c|c|c|c|c|c|c|c|c|c|c|}
\hline & \multirow{2}{*}{$\begin{array}{c}\mathrm{HH} \\
\text { Sample } \\
\text { Size } \\
\\
1996\end{array}$} & \multicolumn{2}{|c|}{$\begin{array}{c}\text { HH. in } \\
\text { population } \\
\text { Extrapolated }\end{array}$} & \multirow[b]{2}{*}{$\begin{array}{c}\text { Sample-Pop } \\
\text { Ratio }\end{array}$} & \multicolumn{2}{|c|}{$50 \%$ pass-through } & \multicolumn{2}{|c|}{$60 \%$ pass-through } & \multicolumn{2}{|c|}{$70 \%$ pass-through } & \multicolumn{2}{|c|}{$100 \%$ pass-through } \\
\hline & & 1996 & 2005 & & $\begin{array}{l}\text { Sample } \\
\text { (DF bil) }\end{array}$ & $\begin{array}{l}\text { Population } \\
\text { (DF bil) }\end{array}$ & $\begin{array}{l}\text { Sample } \\
\text { (DF bil) }\end{array}$ & $\begin{array}{l}\text { Population } \\
\text { (DF bil) }\end{array}$ & $\begin{array}{l}\text { Sample } \\
\text { (DF bil) }\end{array}$ & $\begin{array}{l}\text { Population } \\
\text { (DF bil) }\end{array}$ & $\begin{array}{l}\text { Sample } \\
\text { (DF bil) }\end{array}$ & $\begin{array}{l}\text { Population } \\
\text { (DF bil) }\end{array}$ \\
\hline djibouti-ville 1 & 315 & 6195 & 8083 & 25.7 & 0.05 & 1.16 & 0.07 & 1.88 & 0.11 & 2.94 & 0.24 & 6.13 \\
\hline djibouti-ville - & 484 & 9519 & 12420 & 25.7 & 0.12 & 2.96 & 0.17 & 4.27 & 0.21 & 5.49 & 0.40 & 10.14 \\
\hline djibouti-ville - & 152 & 2989 & 3900 & 25.7 & 0.03 & 0.80 & 0.04 & 1.07 & 0.06 & 1.49 & 0.12 & 3.02 \\
\hline djibouti-ville - & 363 & 7139 & 9315 & 25.7 & 0.08 & 2.16 & 0.11 & 2.84 & 0.14 & 3.56 & 0.23 & 5.81 \\
\hline djibouti-ville - & 277 & 5507 & 7185 & 25.9 & 0.06 & 1.46 & 0.07 & 1.89 & 0.09 & 2.39 & 0.15 & 3.84 \\
\hline ali-sabieh urbai & 147 & 1728 & 2255 & 15.3 & 0.04 & 0.56 & 0.05 & 0.70 & 0.06 & 0.87 & 0.08 & 1.30 \\
\hline dikhil urbain & 124 & 1457 & 1901 & 15.3 & 0.03 & 0.45 & 0.04 & 0.58 & 0.04 & 0.68 & 0.06 & 0.99 \\
\hline arta, wea & 44 & 517 & 675 & 15.3 & 0.01 & 0.16 & 0.01 & 0.19 & 0.02 & 0.24 & 0.02 & 0.38 \\
\hline obock urbain & 25 & 293 & 382 & 15.3 & 0.00 & 0.07 & 0.01 & 0.10 & 0.01 & 0.13 & 0.02 & 0.25 \\
\hline tadjourah urbain & 52 & 624 & 814 & 15.7 & 0.01 & 0.15 & 0.01 & 0.19 & 0.02 & 0.24 & 0.03 & 0.42 \\
\hline ali-sabieh rural & 125 & 813 & 1061 & 8.5 & 0.03 & 0.23 & 0.03 & 0.29 & 0.04 & 0.34 & 0.06 & 0.49 \\
\hline dikhil rural & 77 & 500 & 652 & 8.5 & 0.01 & 0.12 & 0.02 & 0.14 & 0.02 & 0.17 & 0.03 & 0.24 \\
\hline djibouti rural & 114 & 741 & 967 & 8.5 & 0.02 & 0.18 & 0.03 & 0.24 & 0.04 & 0.30 & 0.05 & 0.45 \\
\hline tadjourah rural & 81 & 545 & 711 & 8.8 & 0.01 & 0.13 & 0.02 & 0.16 & 0.02 & 0.19 & 0.03 & 0.27 \\
\hline Total & 2380 & 38567 & 50321 & 21.1 & 0.50 & 10.57 & 0.68 & 14.54 & 0.87 & 19.02 & 1.51 & 33.73 \\
\hline$\%$ of 2005 GDP & - & - & - & - & 0.41 & 8.64 & 0.55 & 11.88 & 0.71 & 15.54 & 1.24 & 27.56 \\
\hline
\end{tabular}

Note: Cost is expressed in billions of 2004 DF. Number of sedentary households (HH) in 1996 are taken from the EDAM 1996 sample design while the numbers in 2005 are obtained by assuming an annual growth rate of $3 \%$ since 1996 .

Table A.5b Djibouti: Real Income Loss to Poor Households due to of $100 \%$ Nom. Devaluation with $30 \%$ Public Wage Indexation

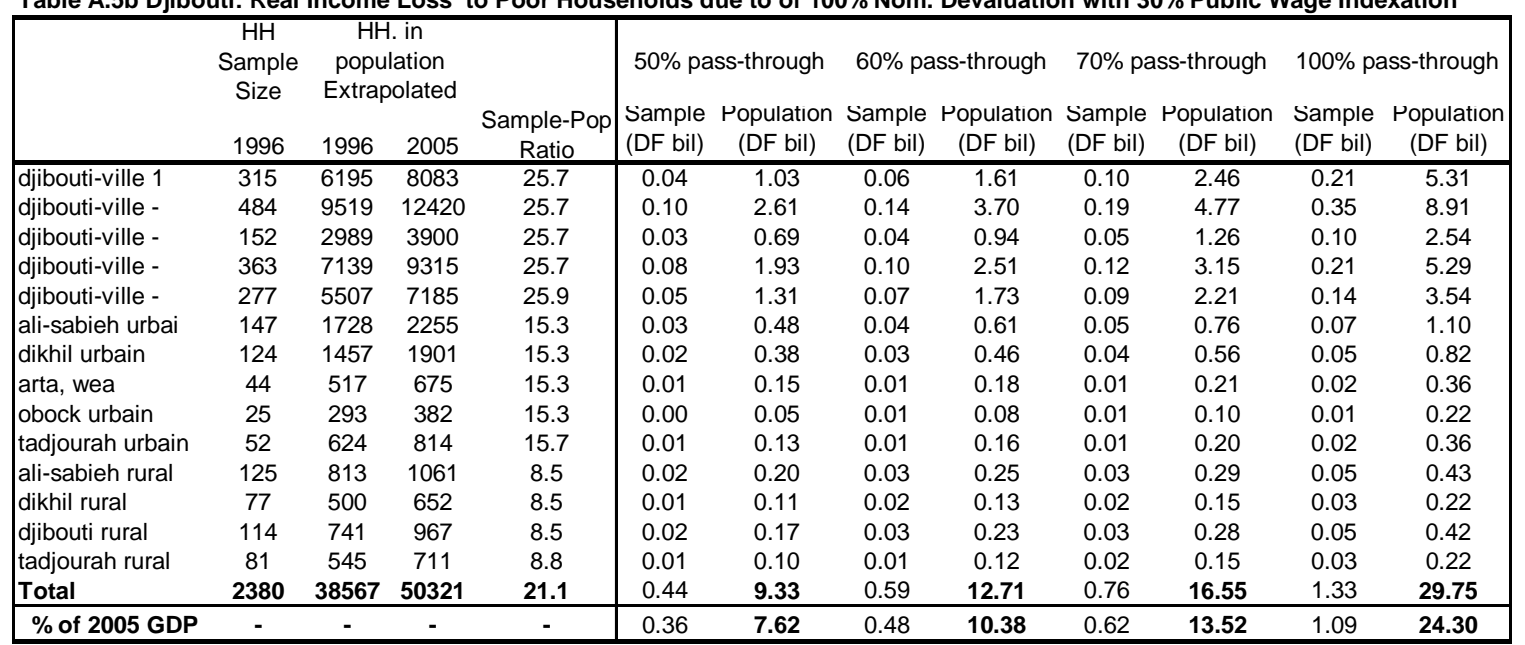

Note: Cost is expressed in billions of 2004 DF. Number of sedentary households (HH) in 1996 are taken from the EDAM 1996 sample design while the numbers in 2005 are obtained by assuming an annual growth rate of $3 \%$ since 1996. 
Table A.6 Djibouti: Real Fiscal Savings and Welfare Gain after a 30\% Nominal Ex. Rate Devaluation

\begin{tabular}{|c|c|c|c|c|c|}
\hline \multicolumn{3}{|c|}{$0 \%$ Wage Indexation } & \multicolumn{3}{|c|}{$30 \%$ Wage Indexation } \\
\hline \multicolumn{3}{|c|}{$50 \%$ pass through } & \multicolumn{3}{|c|}{ 50\% pass through } \\
\hline \multicolumn{2}{|c|}{ Predicted Real Levels '05 (DF bil) } & $\begin{array}{c}\% \text { Chg } \\
\text { (base 04) }\end{array}$ & Predicted Real Levels '05 & = bil) & $\begin{array}{c}\text { \% Chg } \\
\text { (base 04) }\end{array}$ \\
\hline Gov. Revenue & 45.57 & $9.8 \%$ & Gov. Revenue & 45.61 & $9.9 \%$ \\
\hline Gov. Expenditure & 38.96 & $-2.9 \%$ & Gov. Expenditure & 39.33 & $-2.0 \%$ \\
\hline Fiscal Savings & 6.61 & $382.1 \%$ & Fiscal Savings & 6.28 & $358.0 \%$ \\
\hline As \% of real GDP in 2005 & $5.40 \%$ & $4.24 \%$ & As \% of real GDP in 2005 & $5.13 \%$ & $3.97 \%$ \\
\hline Less:Social Transfers (ST) & 1.96 & - & Less:Social Transfers (ST) & 1.78 & - \\
\hline Fiscal Savings Net of ST & 4.65 & - & Fiscal Savings Net of ST & $\overline{4.50}$ & - \\
\hline As \% of real GDP in 2005 & $3.80 \%$ & $2.63 \%$ & As \% of real GDP in 2005 & $3.67 \%$ & $2.51 \%$ \\
\hline Real Public Sector Wages & & $-10.5 \%$ & Real Public Sector Wages & & $18.2 \%$ \\
\hline \multicolumn{3}{|c|}{$60 \%$ pass through } & \multicolumn{3}{|c|}{$\underline{60 \%}$ pass through } \\
\hline \multicolumn{2}{|c|}{ Predicted Real Levels '05 (DF bil) } & $\begin{array}{c}\% \text { Chg } \\
\text { (base 04) }\end{array}$ & \multicolumn{2}{|c|}{ Predicted Real Levels '05 (DF bil) } & $\begin{array}{c}\% \text { Chg } \\
\text { (base 04) }\end{array}$ \\
\hline Gov. Revenue & 44.69 & $7.7 \%$ & Gov. Revenue & 44.74 & $7.9 \%$ \\
\hline Gov. Expenditure & 38.69 & $-3.5 \%$ & Gov. Expenditure & 39.14 & $-2.4 \%$ \\
\hline Fiscal Savings & 6.00 & $337.8 \%$ & Fiscal Savings & 5.61 & $308.9 \%$ \\
\hline As \% of real GDP in 2005 & $4.90 \%$ & $3.74 \%$ & As \% of real GDP in 2005 & $4.58 \%$ & $3.42 \%$ \\
\hline Less:Social Transfers (ST) & 2.44 & - & Less:Social Transfers (ST) & 2.22 & - \\
\hline Fiscal Savings Net of ST & 3.56 & - & Fiscal Savings Net of ST & 3.39 & - \\
\hline As \% of real GDP in 2005 & $2.91 \%$ & $1.75 \%$ & As \% of real GDP in 2005 & $2.77 \%$ & $1.60 \%$ \\
\hline Real Public Sector Wages & & $-12.6 \%$ & Real Public Sector Wages & & $15.8 \%$ \\
\hline \multicolumn{3}{|c|}{ 70\% pass through } & \multicolumn{3}{|c|}{ 70\% pass through } \\
\hline \multicolumn{2}{|c|}{ Predicted Real Levels '05 (DF bil) } & $\begin{array}{l}\% \text { Chg } \\
\text { (base 04) }\end{array}$ & \multicolumn{2}{|c|}{ Predicted Real Levels '05 (DF bil) } & $\begin{array}{c}\% \text { Chg } \\
\text { (base 04) }\end{array}$ \\
\hline Gov. Revenue & 43.82 & $5.6 \%$ & Gov. Revenue & 43.88 & $5.8 \%$ \\
\hline Gov. Expenditure & 38.43 & $-4.2 \%$ & nditure & 38.95 & $-2.9 \%$ \\
\hline Fiscal Savings & 5.40 & $293.5 \%$ & Fiscal Savings & 4.93 & $259.8 \%$ \\
\hline As \% of real GDP in 2005 & $4.41 \%$ & $3.24 \%$ & As \% of real GDP in 2005 & $4.03 \%$ & $2.87 \%$ \\
\hline Less:Social Transfers (ST) & 3.00 & - & Less:Social Transfers (ST) & 2.69 & - \\
\hline Fiscal Savings Net of ST & 2.40 & - & Fiscal Savings Net of ST & 2.24 & - \\
\hline As $\%$ of real GDP in 2005 & $1.96 \%$ & $0.80 \%$ & As \% of real GDP in 2005 & $1.83 \%$ & $0.67 \%$ \\
\hline Real Public Sector Wages & & $-14.7 \%$ & Real Public Sector Wages & & $13.4 \%$ \\
\hline \multicolumn{3}{|c|}{$100 \%$ pass through } & \multicolumn{3}{|c|}{$100 \%$ pass through } \\
\hline \multicolumn{2}{|c|}{ Predicted Real Levels '05 (DF bil) } & $\begin{array}{c}\% \text { Chg } \\
\text { (base 04) }\end{array}$ & \multicolumn{2}{|c|}{ Predicted Real Levels '05 (DF bil) } & $\begin{array}{c}\% \text { Chg } \\
\text { (base 04) }\end{array}$ \\
\hline Gov. Revenue & 41.21 & $-0.7 \%$ & Gov. Revenue & 41.29 & $-0.5 \%$ \\
\hline Gov. Expenditure & 37.64 & $-6.2 \%$ & Gov. Expenditure & 38.38 & $-4.3 \%$ \\
\hline Fiscal Savings & 3.57 & $160.6 \%$ & Fiscal Savings & 2.91 & $112.4 \%$ \\
\hline As \% of real GDP in 2005 & $2.92 \%$ & $1.76 \%$ & As \% of real GDP in 2005 & $2.38 \%$ & $1.22 \%$ \\
\hline Less:Social Transfers (ST) & 4.86 & - & Less:Social Transfers (ST) & 4.33 & - \\
\hline Fiscal Savings Net of ST & -1.29 & - & Fiscal Savings Net of ST & -1.42 & - \\
\hline As \% of real GDP in 2005 & $-1.05 \%$ & $-2.22 \%$ & As \% of real GDP in 2005 & $-1.16 \%$ & $-2.32 \%$ \\
\hline Real Public Sector Wages & & $-21.0 \%$ & Real Public Sector Wages & & $6.3 \%$ \\
\hline
\end{tabular}

Notes:

1. Welfare estimates exclude private sector cost of higher nominal wages.

2. The percentage change column for the share of real fiscal savings to GDP refers to percentage point difference 3. Social Transfers is equivalent to the estimated real income loss to households that will fall below the absolute poverty line (1996 base) after the devaluation.

4. Wage indexation is only applicable to households where the ratio of public sector income to total income exceeds $90 \%$.

5. Real GDP in 2005 is forecasted at DF 122.4 billion (using 2004 as the base year).

Source: Author's calculation based on WEO 2004 
Table A.7 Djibouti: Real Fiscal Savings and Welfare Gain after a 60\% Ex. Rate Nominal Devaluation

\begin{tabular}{|c|c|c|c|c|c|}
\hline \multicolumn{3}{|c|}{$0 \%$ Wage Indexation } & \multicolumn{3}{|c|}{$30 \%$ Wage Indexation } \\
\hline \multicolumn{2}{|c|}{$\underline{50 \%}$ pass through } & \multirow[b]{2}{*}{$\begin{array}{c}\% \text { Chg } \\
\text { (base 04) }\end{array}$} & \multicolumn{3}{|c|}{$\underline{50 \%}$ pass through } \\
\hline \multicolumn{2}{|c|}{ Predicted Real Levels '05 (DF bil) } & & \multicolumn{2}{|c|}{ Predicted Real Levels '05 (DF bil) } & $\begin{array}{l}\% \text { Chg } \\
\text { (base 04) }\end{array}$ \\
\hline Gov. Revenue & 49.65 & $19.7 \%$ & Gov. Revenue & 49.73 & $19.9 \%$ \\
\hline Gov. Expenditure & 37.80 & $-5.8 \%$ & Gov. Expenditure & 38.54 & $-3.9 \%$ \\
\hline Fiscal Savings & 11.85 & $764.2 \%$ & Fiscal Savings & 11.19 & $716.0 \%$ \\
\hline As \% of real GDP in 2005 & $9.68 \%$ & $8.52 \%$ & As $\%$ of real GDP in 2005 & $9.14 \%$ & $7.98 \%$ \\
\hline Less:Social Transfers (ST) & 4.86 & - & Less:Social Transfers (ST) & 4.33 & - \\
\hline Fiscal Savings Net of ST & 6.99 & - & Fiscal Savings Net of ST & 6.86 & - \\
\hline As \% of real GDP in 2005 & $5.7 \%$ & $4.54 \%$ & As \% of real GDP in 2005 & $5.6 \%$ & $4.44 \%$ \\
\hline Real Public Sector Wages & & $-21.0 \%$ & Real Public Sector Wages & & $6.3 \%$ \\
\hline \multicolumn{2}{|c|}{$\underline{60 \%}$ pass through } & & \multicolumn{3}{|c|}{$60 \%$ pass through } \\
\hline \multicolumn{2}{|c|}{ Predicted Real Levels '05 (DF bil) } & $\begin{array}{l}\% \text { Chg } \\
\text { (base 04) }\end{array}$ & \multicolumn{2}{|c|}{ Predicted Real Levels '05 (DF bil) } & $\begin{array}{c}\text { \% Chg } \\
\text { (base 04) }\end{array}$ \\
\hline Gov. Revenue & 47.90 & $15.5 \%$ & Gov. Revenue & 48.00 & $15.7 \%$ \\
\hline Gov. Expenditure & 37.27 & $-7.1 \%$ & Gov. Expenditure & 38.16 & $-4.9 \%$ \\
\hline Fiscal Savings & 10.64 & $675.6 \%$ & Fiscal Savings & 9.84 & $617.8 \%$ \\
\hline As \% of real GDP in 2005 & $8.7 \%$ & $7.5 \%$ & As \% of real GDP in 2005 & $8.0 \%$ & $6.9 \%$ \\
\hline Less:Social Transfers (ST) & 6.29 & - & Less:Social Transfers (ST) & 5.59 & - \\
\hline Fiscal Savings Net of ST & 4.35 & - & Fiscal Savings Net of ST & 4.25 & - \\
\hline As \% of real GDP in 2005 & $3.6 \%$ & $2.4 \%$ & As \% of real GDP in 2005 & $3.5 \%$ & $2.3 \%$ \\
\hline Real Public Sector Wages & & $-25.2 \%$ & Real Public Sector Wages & & $1.6 \%$ \\
\hline \multicolumn{2}{|c|}{ 70\% pass through } & & \multicolumn{3}{|c|}{ 70\% pass through } \\
\hline \multicolumn{2}{|c|}{ Predicted Real Levels '05 (DF bil) } & $\begin{array}{c}\% \text { Chg } \\
\text { (base 04) }\end{array}$ & \multicolumn{2}{|c|}{ Predicted Real Levels '05 (DF bil) } & $\begin{array}{c}\text { \% Chg } \\
\text { (base 04) }\end{array}$ \\
\hline Gov. Revenue & 46.16 & $11.3 \%$ & Gov. Revenue & 46.28 & $11.6 \%$ \\
\hline Gov. Expenditure & 36.74 & $-8.4 \%$ & Gov. Expenditure & 37.78 & $-5.8 \%$ \\
\hline Fiscal Savings & 9.42 & $587.0 \%$ & Fiscal Savings & 8.50 & $519.6 \%$ \\
\hline As \% of real GDP in 2005 & $7.7 \%$ & & As \% of real GDP in 2005 & $6.9 \%$ & $5.8 \%$ \\
\hline Less:Social Transfers (ST) & 7.94 & - & Less:Social Transfers (ST) & 7.04 & - \\
\hline Fiscal Savings Net of ST & 1.48 & - & Fiscal Savings Net of ST & 1.45 & - \\
\hline As \% of real GDP in 2005 & $1.2 \%$ & $0.0 \%$ & As \% of real GDP in 2005 & $1.2 \%$ & $0.0 \%$ \\
\hline Real Public Sector Wages & & $-29.4 \%$ & Real Public Sector Wages & & $-3.2 \%$ \\
\hline \multicolumn{2}{|c|}{$100 \%$ pass through } & & \multicolumn{3}{|c|}{$100 \%$ pass through } \\
\hline \multicolumn{2}{|c|}{ Predicted Real Levels '05 (DF bil) } & $\begin{array}{c}\% \text { Chg } \\
\text { (base 04) }\end{array}$ & \multicolumn{2}{|c|}{ Predicted Real Levels '05 (DF bil) } & $\begin{array}{c}\text { \% Chg } \\
\text { (base 04) }\end{array}$ \\
\hline Gov. Revenue & 40.93 & $-1.3 \%$ & Gov. Revenue & 41.10 & $-0.9 \%$ \\
\hline Gov. Expenditure & 35.16 & $-12.4 \%$ & Gov. Expenditure & 36.64 & $-8.6 \%$ \\
\hline Fiscal Savings & 5.78 & $321.3 \%$ & Fiscal Savings & 4.45 & $224.9 \%$ \\
\hline As \% of real GDP in 2005 & $4.90 \%$ & $3.74 \%$ & As \% of real GDP in 2005 & $3.78 \%$ & $2.62 \%$ \\
\hline Less:Social Transfers (ST) & 14.54 & - & Less:Social Transfers (ST) & 12.71 & - \\
\hline Fiscal Savings Net of ST & -8.76 & - & Fiscal Savings Net of ST & -8.25 & - \\
\hline As \% of real GDP in 2005 & $-7.16 \%$ & $-8.32 \%$ & As $\%$ of real GDP in 2005 & $-6.74 \%$ & $-7.91 \%$ \\
\hline Real Public Sector Wages & & $-42.0 \%$ & Real Public Sector Wages & & $-17.4 \%$ \\
\hline
\end{tabular}

Notes:

1. Welfare estimates exclude private sector cost of higher nominal wages.

2. The percentage change column for the share of real fiscal savings to GDP refers to percentage point difference between 2004 and the estimate share in 2005.

3. Social Transfers is equivalent to the estimated real income loss to households that will fall below the absolute poverty line (1996 base) after the devaluation.

4. Wage indexation is only applicable to households where the ratio of public sector income to total income exceeds $90 \%$.

5. Real GDP in 2005 is forecasted at DF 122.4 billion (using 2004 as the base year).

Source: Author's calculation based on WEO 2004 
Table A.8 Djibouti: Real Fiscal Savings and Welfare Gain after a 100\% Ex. Rate Nominal Devaluation

\begin{tabular}{|c|c|c|c|c|c|}
\hline \multicolumn{3}{|c|}{$0 \%$ Wage Indexation } & \multicolumn{3}{|c|}{$30 \%$ Wage Indexation } \\
\hline \multicolumn{3}{|c|}{ 50\% pass through } & \multicolumn{3}{|c|}{$50 \%$ pass through } \\
\hline \multicolumn{2}{|c|}{ Predicted Real Levels '05 (DF bil) } & $\begin{array}{c}\text { \% Chg } \\
\text { (base 04) }\end{array}$ & \multicolumn{2}{|c|}{ Predicted Real Levels '05 (DF bil) } & $\begin{array}{l}\text { \% Chg } \\
\text { (base 04) }\end{array}$ \\
\hline Gov. Revenue & 55.09 & $32.8 \%$ & Gov. Revenue & 55.22 & $33.1 \%$ \\
\hline Gov. Expenditure & 36.25 & $-9.6 \%$ & Gov. Expenditure & 37.49 & $-6.5 \%$ \\
\hline Fiscal Savings & 18.84 & $1273.7 \%$ & Fiscal Savings & 17.73 & $1193.4 \%$ \\
\hline As \% of real GDP in 2005 & $15.39 \%$ & $14.22 \%$ & As \% of real GDP in 2005 & $14.49 \%$ & $13.32 \%$ \\
\hline Less:Social Transfers (ST) & 10.57 & - & Less:Social Transfers (ST) & 9.33 & - \\
\hline Fiscal Savings Net of ST & 8.26 & - & Fiscal Savings Net of ST & $\overline{8.41}$ & - \\
\hline As $\%$ of real GDP in 2005 & $6.75 \%$ & $5.58 \%$ & As \% of real GDP in 2005 & $6.9 \%$ & $5.71 \%$ \\
\hline Real Public Sector Wages & & $-35.0 \%$ & Real Public Sector Wages & & $-9.5 \%$ \\
\hline \multicolumn{3}{|c|}{$\underline{60 \%}$ pass through } & \multicolumn{3}{|c|}{$60 \%$ pass through } \\
\hline \multicolumn{2}{|c|}{ Predicted Real Levels '05 (DF bil) } & $\begin{array}{l}\% \text { Chg } \\
\text { (base 04) }\end{array}$ & \multicolumn{2}{|c|}{ Predicted Real Levels '05 (DF bil) } & $\begin{array}{l}\% \text { Chg } \\
\text { (base 04) }\end{array}$ \\
\hline Gov. Revenue & 52.18 & 25.8 & Gov. Revenue & 52.35 & $26.2 \%$ \\
\hline Gov. Expenditure & 35.37 & -11 & Gov. Expenditure & 36.86 & $-8.1 \%$ \\
\hline Fiscal Savings & 16.81 & 1126 & Fiscal Savings & 15.49 & $1029.7 \%$ \\
\hline As \% of real GDP in 2005 & $13.73 \%$ & 12.5 & As \% of real GDP in 2005 & $12.65 \%$ & $11.49 \%$ \\
\hline Less:Social Transfers (ST) & 14.54 & - & Less:Social Transfers (ST) & 12.71 & - \\
\hline Fiscal Savings Net of ST & 2.27 & - & Fiscal Savings Net of ST & 2.78 & - \\
\hline As \% of real GDP in 2005 & $1.9 \%$ & $0.69 \%$ & As $\%$ of real GDP in 2005 & $2.3 \%$ & $1.11 \%$ \\
\hline Real Public Sector Wages & & $-42.0 \%$ & Real Public Sector Wages & & $-17.4 \%$ \\
\hline \multicolumn{3}{|c|}{$\underline{70 \%}$ pass through } & \multicolumn{3}{|c|}{ 70\% pass through } \\
\hline \multicolumn{2}{|c|}{ Predicted Real Levels '05 (DF bil) } & $\begin{array}{l}\% \text { Chg } \\
\text { (base 04) }\end{array}$ & \multicolumn{2}{|c|}{ Predicted Real Levels '05 (DF bil) } & $\begin{array}{l}\text { \% Chg } \\
\text { (base 04) }\end{array}$ \\
\hline Gov. Revenue & 49.28 & $18.8 \%$ & Gov. Revenue & 49.47 & $19.3 \%$ \\
\hline Gov. Expenditure & 34.49 & $-14.0 \%$ & Gov. Expenditure & 36.23 & $-9.7 \%$ \\
\hline Fiscal Savings & 14.79 & $978.4 \%$ & Fiscal Savings & 13.24 & $866.0 \%$ \\
\hline As \% of real GDP in 2005 & $12.08 \%$ & $10.92 \%$ & As $\%$ of real GDP in 2005 & $10.82 \%$ & $9.66 \%$ \\
\hline Less:Social Transfers (ST) & 19.02 & - & Less:Social Transfers (ST) & 16.55 & - \\
\hline Fiscal Savings Net of ST & -4.23 & - & Fiscal Savings Net of ST & -3.30 & - \\
\hline As \% of real GDP in 2005 & $-3.5 \%$ & $-4.62 \%$ & As $\%$ of real GDP in 2005 & $-2.7 \%$ & $-3.86 \%$ \\
\hline Real Public Sector Wages & & $-49.0 \%$ & Real Public Sector Wages & & $-25.3 \%$ \\
\hline \multicolumn{3}{|c|}{$\underline{100 \% \text { pass through }}$} & \multicolumn{3}{|c|}{$100 \%$ pass through } \\
\hline \multicolumn{2}{|c|}{ Predicted Real Levels '05 (DF bil) } & $\begin{array}{c}\% \text { Chg } \\
\text { (base 04) }\end{array}$ & \multicolumn{2}{|c|}{ Predicted Real Levels '05 (DF bil) } & $\begin{array}{l}\text { \% Chg } \\
\text { (base 04) }\end{array}$ \\
\hline Gov. Revenue & 40.57 & $-2.2 \%$ & Gov. Revenue & 40.84 & $-1.5 \%$ \\
\hline Gov. Expenditure & 31.85 & $-20.6 \%$ & Gov. Expenditure & 34.33 & $-14.4 \%$ \\
\hline Fiscal Savings & 8.71 & $535.4 \%$ & Fiscal Savings & 6.51 & $374.8 \%$ \\
\hline As \% of real GDP in 2005 & $7.12 \%$ & $5.95 \%$ & As $\%$ of real GDP in 2005 & $5.32 \%$ & $4.15 \%$ \\
\hline Less:Social Transfers (ST) & 33.73 & - & Less:Social Transfers (ST) & 29.75 & - \\
\hline Fiscal Savings Net of ST & -25.02 & - & Fiscal Savings Net of ST & -23.24 & - \\
\hline As \% of real GDP in 2005 & $-20.44 \%$ & $-21.60 \%$ & As \% of real GDP in 2005 & $-18.98 \%$ & $-20.15 \%$ \\
\hline Real Public Sector Wages & & $-70.0 \%$ & Real Public Sector Wages & & $-49.0 \%$ \\
\hline
\end{tabular}

Notes:

1. Welfare estimates exclude private sector cost of higher nominal wages.

2. The percentage change column for the share of real fiscal savings to GDP refers to percentage point difference between 2004 and the estimate share in 2005.

3. Social Transfers is equivalent to the estimated real income loss to households that will fall below the absolute poverty line (1996 base) after the devaluation.

4. Wage indexation is only applicable to households where the ratio of public sector income to total income exceeds $90 \%$.

5. Real GDP in 2005 is forecasted at DF 122.4 billion (using 2004 as the base year).

Source: Author's calculation based on WEO 2004 
Table A9 Djibouti: Real Fiscal Savings with wage indexation to maintain constant real wages

\begin{tabular}{|c|c|c|c|c|c|}
\hline \multicolumn{3}{|c|}{$30 \%$ Nominal Dev } & \multicolumn{3}{|c|}{$60 \%$ Nominal Dev } \\
\hline \multicolumn{3}{|c|}{ 50\% pass through } & \multicolumn{3}{|c|}{$50 \%$ pass through } \\
\hline \multicolumn{2}{|c|}{ Predicted Real Levels '05 (DF bil) } & $\begin{array}{c}\% \text { Chg } \\
\text { (base 04) }\end{array}$ & Predicted Real Levels ' 0 & F bil) & $\begin{array}{c}\text { \% Chg } \\
\text { (base 04) }\end{array}$ \\
\hline Gov. Revenue & 45.58 & $9.9 \%$ & Gov. Revenue & 49.71 & $19.8 \%$ \\
\hline Gov. Expenditure & 39.09 & $-2.5 \%$ & Gov. Expenditure & 38.37 & $-4.4 \%$ \\
\hline Fiscal Savings & 6.49 & $373.3 \%$ & Fiscal Savings & 11.34 & $727.1 \%$ \\
\hline As \% of real GDP in 2005 & $5.30 \%$ & $4.14 \%$ & As \% of real GDP in 2005 & $9.27 \%$ & $8.10 \%$ \\
\hline Less:Social Transfers (ST) & 1.89 & - & Less:Social Transfers (ST) & 4.44 & - \\
\hline Fiscal Savings Net of ST & 4.60 & - & Fiscal Savings Net of ST & 6.90 & - \\
\hline As \% of real GDP in 2005 & $3.75 \%$ & $2.59 \%$ & As \% of real GDP in 2005 & $5.6 \%$ & - \\
\hline Wage Indexation & & $11.0 \%$ & Wage Indexation & & $23.1 \%$ \\
\hline \multicolumn{3}{|c|}{$60 \%$ pass through } & \multicolumn{3}{|c|}{ 60\% pass through } \\
\hline \multicolumn{2}{|c|}{ Predicted Real Levels '05 (DF bil) } & $\begin{array}{c}\% \text { Chg } \\
\text { (base 04) }\end{array}$ & \multicolumn{2}{|c|}{ Predicted Real Levels '05 (DF bil) } & $\begin{array}{c}\% \text { Chg } \\
\text { (base 04) }\end{array}$ \\
\hline Gov. Revenue & 44.72 & $7.8 \%$ & Gov. Revenue & 48.00 & $15.7 \%$ \\
\hline Gov. Expenditure & 38.89 & $-3.0 \%$ & Gov. Expenditure & 38.11 & $-5.0 \%$ \\
\hline Fiscal Savings & 5.83 & $324.9 \%$ & Fiscal Savings & 9.89 & $621.1 \%$ \\
\hline As \% of real GDP in 2005 & $4.76 \%$ & $3.60 \%$ & As \% of real GDP in 2005 & $8.1 \%$ & $6.9 \%$ \\
\hline Less:Social Transfers (ST) & 2.33 & - & Less:Social Transfers (ST) & 5.62 & - \\
\hline Fiscal Savings Net of ST & 3.50 & - & Fiscal Savings Net of ST & 4.27 & - \\
\hline As \% of real GDP in 2005 & $2.86 \%$ & - & As \% of real GDP in 2005 & $3.5 \%$ & - \\
\hline Wage Indexation & & $13.4 \%$ & Wage Indexation & & $28.3 \%$ \\
\hline \multicolumn{3}{|c|}{ 70\% pass through } & \multicolumn{3}{|c|}{ 70\% pass through } \\
\hline \multicolumn{2}{|c|}{ Predicted Real Levels '05 (DF bil) } & $\begin{array}{c}\% \text { Chg } \\
\text { (base 04) }\end{array}$ & \multicolumn{2}{|c|}{ Predicted Real Levels '05 (DF bil) } & $\begin{array}{c}\text { \% Chg } \\
\text { (base 04) }\end{array}$ \\
\hline Gov. Revenue & 43.85 & $5.7 \%$ & Gov. Revenue & 46.29 & $11.6 \%$ \\
\hline Gov. Expenditure & 38.70 & -3 & Gov. Expenditure & 37.91 & $-5.5 \%$ \\
\hline Fiscal Savings & 5.15 & $275.8 \%$ & Fiscal Savings & 8.38 & $511.3 \%$ \\
\hline As \% of real GDP in 2005 & $4.21 \%$ & $3.05 \%$ & As \% of real GDP in 2005 & $6.8 \%$ & $5.7 \%$ \\
\hline Less:Social Transfers (ST) & 2.81 & - & Less:Social Transfers (ST) & 6.93 & - \\
\hline Fiscal Savings Net of ST & 2.35 & - & Fiscal Savings Net of ST & 1.45 & - \\
\hline As \% of real GDP in 2005 & $1.92 \%$ & - & As \% of real GDP in 2005 & $1.2 \%$ & - \\
\hline Wage Indexation & & $15.8 \%$ & Wage Indexation & & $33.7 \%$ \\
\hline \multicolumn{3}{|c|}{$\underline{100 \% \text { pass through }}$} & \multicolumn{3}{|c|}{$100 \%$ pass through } \\
\hline \multicolumn{2}{|c|}{ Predicted Real Levels '05 (DF bil) } & $\begin{array}{l}\% \text { Chg } \\
\text { (base 04) }\end{array}$ & \multicolumn{2}{|c|}{ Predicted Real Levels '05 (DF bil) } & $\begin{array}{c}\text { \% Chg } \\
\text { (base 04) }\end{array}$ \\
\hline Gov. Revenue & 41.27 & $-0.5 \%$ & Gov. Revenue & 41.22 & $-0.6 \%$ \\
\hline Gov. Expenditure & 38.21 & $-4.8 \%$ & Gov. Expenditure & 37.70 & $-6.0 \%$ \\
\hline Fiscal Savings & 3.06 & $123.5 \%$ & Fiscal Savings & 3.52 & $156.5 \%$ \\
\hline As \% of real GDP in 2005 & $2.50 \%$ & $1.34 \%$ & As \% of real GDP in 2005 & $2.98 \%$ & $1.82 \%$ \\
\hline Less:Social Transfers (ST) & 4.44 & - & Less:Social Transfers (ST) & 11.84 & - \\
\hline Fiscal Savings Net of ST & -1.37 & - & Fiscal Savings Net of ST & -8.32 & - \\
\hline As \% of real GDP in 2005 & $-1.12 \%$ & - & As \% of real GDP in 2005 & $-6.80 \%$ & - \\
\hline Wage Indexation & & $23.1 \%$ & Wage Indexation & & $51.3 \%$ \\
\hline
\end{tabular}

Notes:

1. Welfare estimates exclude private sector cost of higher nominal wages.

2. The percentage change column for the share of real fiscal savings to GDP refers to percentage point difference between 2004 and the estimate share in 2005.

3. Social Transfers is equivalent to the estimated real income loss to households that will fall below the absolute poverty line (1996 base) after the devaluation.

4. Wage indexation is only applicable to households where the ratio of public sector income to total income exceeds $90 \%$.

5. Real GDP in 2005 is forecasted at DF 122.4 billion (using 2004 as the base year).

Source: Author's calculation based on WEO 2004 